Original Research Paper

\title{
Design and Dynamic Simulation of a Combined System Integration Concentrating Photovoltaic/Thermal Solar Collectors and Organic Rankine Cycle
}

\author{
${ }^{1}$ Francesco Calise, ${ }^{1}$ Massimo Dentice d'Accadia, ${ }^{1}$ Maria Vicidomini, ${ }^{2}$ Gabriele Ferruzzi and ${ }^{2}$ Laura Vanoli \\ ${ }^{1}$ DII, University of Naples Federico II, P.leTecchio 80, 80125 Naples, Italy \\ ${ }^{2}$ DI, University of Naples Parthenope, Centro Direz. IS.C4, 80143 Naples, Italy
}

\author{
Article history \\ Received: 14-02-2015 \\ Revised: $13-03-2015$ \\ Accepted: 10-04-2015 \\ Corresponding Author: \\ Francesco Calise \\ DII, University of Naples \\ Federico II, P.leTecchio 80, \\ 80125 Naples, Italy \\ E-mail: francesco.calise@unina.it
}

\begin{abstract}
This study presents the design of a novel ultra-high efficient solar power system. The system is equipped with a concentrating PhotoVoltaic/Thermal (CPVT) solar collectors bottomed by an Organic Rankine Cycle (ORC). The basic idea is to use a high temperature CPVT device producing simultaneously electricity and hot diathermic oil. Then, this hot fluid is used to supply heat to the Organic Rankine Cycle producing additional electricity. The collector is based on a combination of a parabolic dish concentrating solar thermal collector and a high efficiency solar photovoltaic collector. Among the possible high-temperature PVT systems, this paper is focused on a system consisting in a dish concentrator and in a triple-junction PV layer. In particular, the prototype consists in a parabolic dish concentrator and a planar receiver. The system is equipped with a double axis tracking system. The bottom surface of the receiver is equipped with triple-junction silicon cells whereas the top surface is insulated. Similarly, the ORC subsystem is equipped with tube and shell heat exchangers, a pump and an expander. In order to analyze the performance of the CPVT collector and ORC cycle, detailed mathematical models were implemented. These models are based on zero-dimensional energy balances on the control volumes of the system. The simulation model allows one to calculate in detail the temperatures of the main components of the system and the main energy flows. Both CPVT and ORC models are integrated in a more complex dynamic simulation model, developed in TRNSYS environment. Here, additional components are included in the system: Pump, tank, controllers, valves, etc. The input parameters of the model include weather conditions (temperature, insolation, wind velocity, etc.) and the geometrical/material parameters of the systems. This novel system was compared with a more conventional one, consisting of a concentrating PV collector equipped with III-V cells. Results showed that such second system (only CPVT) is more profitable from an economical point of view, with a 20 years Net Present Value $15 \%$ higher than the novel system (CPVT+ORC). Conversely, the novel (ORC+CPVT) system produces $6 \%$ more electrical energy.
\end{abstract}

Keywords: PVT, Triple-Junction, Solar Energy, Organic Rankine Cycle

\section{Introduction}

Solar energy is commonly considered as one of the most viable types of renewable energy sources, since its availability is significantly higher than the overall worldwide energy demand (Chow, 2010). Unfortunately, solar technology suffers for high capital costs and very low power density, especially when compared to the conventional systems based on fossil fuels. However, during the last few years, a special effort has been performed in order to promote environmental-friendly energy sources, other than fossil fuels (Calise et al., 2014a; 2012; 2015; Daghigh et al., 2011; El-Emam and Dincer, 2013). 
Solar energy is typically used to produce heat and electricity, respectively by Solar thermal Collectors (SC) and solar Photovoltaic (PV) collectors. Electricity can be also produced by solar power plants, including high temperature solar thermal collectors and thermallydriven engines (such as Organic Rankine Cycles, ORC) (Calise et al., 2015). It is also worth noting that hybrid configurations are also possible, where a single system can produce simultaneously electricity and heat, as in Photovoltaic/Thermal collectors (PVT) (Buonomano et al., 2013a) or cogenerative solar power plants (Buonomano et al., 2015).

A Photovoltaic/Thermal Collector (PVT) produces simultaneously electricity and heat. A PVT collector consists of a conventional thermal collector whose absorber is covered by a suitable PV layer (Chow, 2010). The absorbed thermal energy is distributed to a fluid (typically air or water), whereas the PV produces electricity (Chow, 2010; Erdil et al., 2008). Concentrating PVT Collectors (CPVT) consist in PVT collectors placed in the focus of some reflectors (Fresnel, parabolic, dish, etc.) (Chow, 2010; Daghigh et al., 2011; Tripanagnostopoulos, 2007). Note also that CPVT can only convert the beam fraction of the total radiation. Therefore, when the beam-to-total radiation ratio is low, these devices may be scarcely convenient with respect to the conventional PVT. For high-temperature CPVT systems the most suitable PV material is the triplejunction PV whose nominal efficiency of $40 \%$ (at $25^{\circ} \mathrm{C}$ ) drops around $20 \%$ at $240^{\circ} \mathrm{C}$. However, commercially or pre-commercially available CPVT systems are typically a small amount of the PVT under development (Vorobiev et al., 2006). Similarly, the availability of theoretical and experimental studies investigating CPVT performance is scarce. In particular, Buonomano et al. (2012; Kribus et al., 2006; Mittelman et al., 2007a; 2007b) performed some experimental and theoretical works dealing with CPVT systems. In reference (Mittelman et al., 2007a) presented a novel miniature CPVT based on a dish concentrator $\left(0.95 \mathrm{~m}^{2}\right)$ and a silicon PV cell. A thermal model for that system was developed in order to predict its performance. The system provides $140-180 \mathrm{~W}$ of electricity and 400-500 $\mathrm{W}$ of heat. The cost of the system was evaluated at $2.5 \$$ per peak electric watt. Parabolic Trough CPVT were also investigated by (Li et al., 2011a; 2011b; 2011c) comparing the electrical and thermal efficiencies of the system varying the PV technology, for different concentration ratios. Authors concluded that GeAs cells increase electrical efficiency with respect to silicon cells. However, the thermal efficiency of GeAs results lower than the one of silicon cells. Authors also pointed out that the cost of unit area of the GeAs is 3067.16 $\$ / \mathrm{m}^{2}$ versus the $131.34 \$ / \mathrm{m}^{2}$ of the silicon cell. Recently, some of the authors also presented some studies regarding CPVT collectors, investigating the possibility to integrate such devices in solar heating and cooling systems (Calise et al., 2012; 2014b; 2013a) and in polygeneration systems including desalination (Calise et al., 2014a; 2014c).

As mentioned before, another possibility to produce electricity is to couple solar thermal collectors and thermally-driven engines, such as Organic Rankine cycles (Buonomano et al., 2014; Kane et al., 2003; Hoffschmidt et al., 2012; Madhawa et al., 2007; Hung et al., 2010; Kuo et al., 2011; Yamamoto et al., 2001; Yiping et al., 2009). Usually, small-scale solar power systems are based on concentrating solar thermal collectors and volumetric expanders (Quoilin et al., 2010). ORC are dramatically sensitive to the appropriate fluid selection. Calise et al. (2013b) investigated the performance of the ORC system by using different working fluids and varying the heat source temperature level from 120 to $300^{\circ} \mathrm{C}$. The authors stated that two organic mediums are suitable for the exploitation of low to high temperature heat sources, namely, n-Butane and Isobutane, while the R245fa can be used when the heat source temperature reaches up to $170^{\circ} \mathrm{C}$. Many authors simulated and modeled the ORC with various methods. For example, Quoilin et al. (2010) presented both numerical and experimental analyses of an ORC system using R-123 as a working fluid; the experimental study demonstrated the importance of using adapted positive displacement compressor as expander in small scale ORC system. Quoilin et al. (2010; 2011a; Declaye et al., 2012; Quoilin et al., 2011b) investigated the design of a smallscale solar ORC for rural electrification purposes; the model-developed in Engineering Equation Solver (EES) environment-was used to design the components of the cycle and to calculate the ORC performance under different working fluids and expansion machine configurations, single and double stage. Solar power plants are commonly based on concentrating solar collectors. In particular, Parabolic Trough Collectors (PTCs), Fresnel (particularly suitable for solar ORCs, since they require a lower investment cost, but work at lower temperature) and others. In fact, for conventional systems, solar concentrating collectors can achieve the temperatures required to drive a heat engine. In conventional stationary non-concentrating solar thermal collectors, outlet temperature is too low for such kind of applications. Regarding PTCs, the National Renewable Energy Laboratory (NREL) (Price and Hassani, 2002) analyzed a small scale Modular Trough Power Plant (MTPP, from 500 to $1500 \mathrm{~kW}_{\mathrm{e}}$ ) consisting in a Concentrating Solar Parabolic using diathermic oil as a heat transfer fluid and an ORC turbine with pentane as a working fluid. Different cycles are analyzed: Conventional, superheated and regenerated. The maximum temperature of the cycle is $304^{\circ} \mathrm{C}$. Results 
show that the best configuration from a technical point of view is achieved in case of regenerated cycles. The results of the economic analysis show that the system is scarcely competitive without incentives. Kosmadakis et al. (2011) replaced the PTC included in conventional solar ORC power plants with Concentrating Photovoltaic/Thermal (CPVT) solar collectors, in order to increase the electrical production and the system efficiency. Such configuration shows an electrical efficiency of $11.83 \%$, higher than that achieved by the CPVT collectors alone (9.81\%). Ksayer (2011) investigated the thermal recovery from the condenser of a solar ORC cycle. The author pointed out that the advantages of the ORC system are the electricity generation, the hot water production and the low cost compared to photovoltaic electric power generation. A model for a typical parabolic trough solar thermal power generation system with Organic Rankine Cycle (PTSEGS-ORC) was built within the transient energy simulation package TRNSYS by (He et al., 2012) analysing the effects of several key parameters. The study shows that the variation of heat collecting efficiency with oil flow rate increases sharply and then approaches a constant value. In addition, the optimal volume of the thermal storage system was found sensitively dependent on the solar radiation intensity.

As mentioned before, the analysis of the open literature shows a large number of papers investigating separately ORC and CPVT systems. However, in authors' knowledge none of those papers has ever analysed the possibility to couple high temperature CPVT collector with ORC cycles to enhance the overall electrical efficiency of the system. In fact, the basic idea of this paper is to use high temperature CPVT collectors to produce a hot fluid around $100^{\circ} \mathrm{C}$ to be used to drive an ORC power plant. On the other hand, it must be also considered that a large increase of the operating temperature of the CPVT may lead to a corresponding decrease in CPVT electrical efficiency. Such decrease in CPVT power capacity must be compared with the increase in power due to the ORC operation. To this scope, in this paper a further system is also analysed. This system includes the sole CPVT cooled by a heat exchanger. This study aims at calculating in which conditions the proposed novel solar system is better than the conventional one, from both energetic and economic points of view. For this scope both systems are accurately modelled and dynamically simulated in TRNSYS environment.

\section{Systems Layout}

As mentioned before, in order to perform an adequate comparison, the proposed novel solar power system was compared with a more conventional one. In particular, the hybrid CPVT+ORC was compared with a similar CPVT collector, simply cooled by the same fluid used for the ORC condenser. The layouts of the two systems under investigation are shown in Fig. 1.

The first system layout consists of the CPVT collectors and a heat exchanger (diathermic oil Vs. water), which reduces the outlet operating temperature of the diathermic oil and as a consequence, an increase of electrical efficiency of CPVT is obtained.

The second system layout consists of the CPVT collectors and an ORC system. The produced thermal energy feeds the ORC in order to produce electrical energy.

This leads to an increase of the overall electrical efficiency of the system.

The first system includes the following main loops:

- SCHF: Solar Collector Hot Fluid, yellow line in

Figure 1, i.e.: The diathermic oil flowing between the solar field and the heat exchanger:

- $\mathrm{CW}$ : Cooling Water, light blue line in

Figure 1, i.e.: The water cooling the diathermic oil by the heat exchanger.

The second system includes the following main circuits:

- SCF: Solar Collector Fluid, green line in

Figure 1, i.e.: The diathermic oil flowing between the solar field and the storage tank:

- HF: Hot Fluid, orange line in

Figure 1, i.e.: The diathermic oil flowing between the storage tank and the storage tank:

- $\mathrm{CW}$ : Cooling Water, blue line in

Figure 1, i.e.: The water which cools the ORC condenser:

- OF: Organic Fluid, fuchsia line in

Figure 1, i.e.: The R245fa fluid flowing into ORC system.

Both systems are based on the following main components:

- SC: Solar Collectors, consisting of a field of Concentrating Photo Voltaic Thermal collectors

- HE: Heat Exchanger which cools the outlet diathermic oil from SC with cooling water 
- $\quad$ ORC: Organic Rankine Cycle machine, consisting of a $50 \mathrm{~kW}_{\mathrm{e}}$ system adopting R245fa as working fluid

- TK: Diathermic oil stratified vertical storage tank

- P1: Diathermic oil constant speed Pump

- P2: Water variable speed Pump for cooling the diathermic oil by heat exchanger

- P3: Diathermic oil variable speed Pump

- P4: Diathermic oil constant speed Pump

- P5: R245fa ORC machine Pump

- P6: Water constant speed Pump for ORC condenser cooling

In order to compare the performances of the first and second system, the solar field size, i.e., the number of the CPVT solar collectors, in both systems is same, equal to $130\left(1560 \mathrm{~m}^{2}\right)$. Such value was evaluated sizing the solar field able to provide the needed heat for supplying the evaporator of the ORC machine. The rated power of ORC machine is $50 \mathrm{~kW}_{\mathrm{e}}$. In the first system, the diathermic oil flow rate of the pump P1 is equal to the rated diathermic oil rate flow rate of the variable speed pump P3 in the second system. Finally, the temperature of the cooling water flow rate (equal to $25^{\circ} \mathrm{C}$ ) of the pump $\mathrm{P} 2$ (for cooling the diathermic oil by heat exchanger in the first system) and of the pump P6 (for cooling the condenser of ORC in the second system) are the same. Such assumptions are considered in order to perform an appropriate comparison between the two considered systems.

The operating principle of the first system can be summarized as follows. The solar collectors are supplied by the diathermic oil constant speed pump P1. The heated diathermic oil is subsequently cooled by heat exchanger $\mathrm{HE}$, using water at $25^{\circ} \mathrm{C}$. It is worth noting that, for an appropriate comparison with the second system, the same CPVT fluid is considered (diathermic oil); avoiding a possible direct water cooling of the collector. Pump P2 is managed by a feedback controller aiming at controlling CPVT operating temperature. In particular, the controller returns a control signal used to vary the $\mathrm{P} 2$ mass flow rate, in order to achieve the desired set point temperature $\left(35^{\circ} \mathrm{C}\right)$ of outlet diathermic oil from HE.

Then, the cooled diathermic oil passes through the constant flow rate pump P1. For the operation of pump P1, the considered control signal allows pump operation if the solar radiation is greater than $10 \mathrm{~W} / \mathrm{m}^{2}$ and the solar collectors outlet temperature is greater than the inlet one.

The operating principle of the second system can be summarized as follows. The solar collectors are managed by a feedback controller operating on the variable speed pump P3. In particular, such controller receives temperature readings measured at the bottom of TK (i.e., solar collector inlet temperature) and at the outlet of the solar collector loop. The controller returns a control signal used to vary the P3 mass flow rate, in order to achieve the desired outlet set point temperature $\left(110^{\circ} \mathrm{C}\right)$. In addition, the controller also stops pump P3 when the $\mathrm{SC}$ outlet temperature is lower than the TK bottom temperature, since in such case the solar field would dissipate heat. Such controller also receives the measured value of the incident beam solar radiation, stopping the pump P3 when the irradiance falls below $10 \mathrm{~W} / \mathrm{m}^{2}$, so preventing heat dissipation. Thus, the hot diathermic oil produced by the solar loop supplies the heat side of tank TK. On the load side of this tank, the fluid is pumped by pump $\mathrm{P} 4$ to the ORC primary heat exchanger.

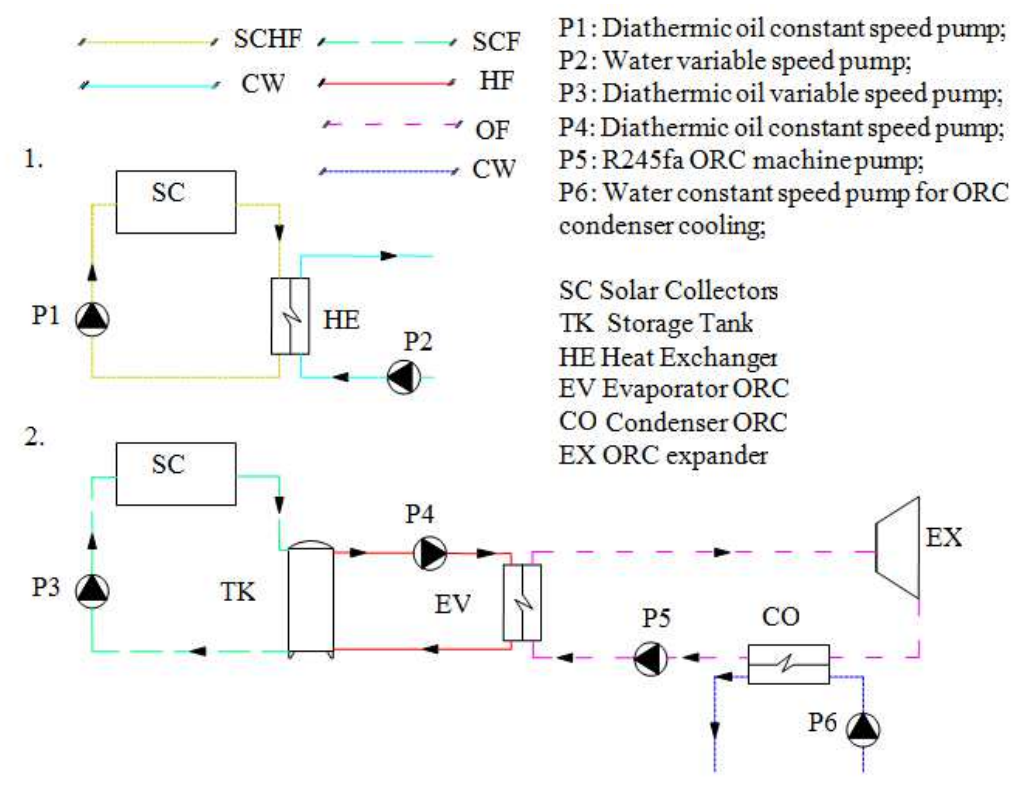

Fig. 1. Systems layout 
The reference configuration of the systems is detailed in Table 1.

The ORC is designed in order to operate at variable temperature $\left(90-130^{\circ} \mathrm{C}\right)$ and fixed flow rate. Therefore P4 is a fixed speed pump. Thus, the ORC produces electrical energy and the condenser of the ORC is cooled by water. The operation of the ORC is not continuous. In fact, ORC and pump P4 are stopped when TK top temperature falls below $90^{\circ} \mathrm{C}$. Subsequently, the solar loop can increase the temperature of the tank TK. When, the top temperature of the tank reaches again $130^{\circ} \mathrm{C}$, ORC and pump $\mathrm{P} 4$ are re-activated. They remain activated until the top temperature of TK is higher than $90^{\circ} \mathrm{C}$.

In Table 2 and 3 respectively, the design parameters of CPVT and ORC machine are shown.

Table 1. Common parameters

\begin{tabular}{|c|c|c|c|}
\hline Parameter & Description & Value & Unit \\
\hline \multicolumn{4}{|l|}{$\begin{array}{l}\text { CPVT } \\
\end{array}$} \\
\hline$N_{S C}$ & Number of Solar Collectors & 130 & / \\
\hline$A_{S C}$ & Solar Collector Area & 1560 & $\mathrm{~m}^{2}$ \\
\hline$q_{P 1}$ & P1 flow rate per unit SC area & 100 & $1 / \mathrm{h} \mathrm{m}^{2}$ \\
\hline$q_{P 2}$ & P2 nominal flow rate & 144000 & $\mathrm{~kg} / \mathrm{h}$ \\
\hline$T_{i n H E}$ & HE inlet cooling water temperature & 25 & ${ }^{\circ} \mathrm{C}$ \\
\hline$A_{H E}$ & Heat Exchanger area & 20 & $\mathrm{~m}^{2}$ \\
\hline \multicolumn{4}{|c|}{ CPVT+ORC } \\
\hline$N_{S C}$ & Number of Solar Collectors & 130 & / \\
\hline$A_{S C}$ & Solar Collector Area & 1560 & $\mathrm{~m}^{2}$ \\
\hline$v_{T K}$ & Tank TK Volume per unit SC aperture area & 5 & $1 / \mathrm{m}^{2}$ \\
\hline$q_{P 3}$ & P3 nominal flow rate per unit SC area & 100 & $1 / \mathrm{h} \mathrm{m}^{2}$ \\
\hline$q_{P 4}$ & P4 flow rate & 16200 & $\mathrm{~kg} / \mathrm{h}$ \\
\hline$T_{\text {set }, S C}$ & Solar collectors outlet set point temperature & 110 & ${ }^{\circ} \mathrm{C}$ \\
\hline$T_{T K, \min }$ & Minumum value of TK top temperature for ORC activation & 90 & ${ }^{\circ} \mathrm{C}$ \\
\hline$T_{T K, a c t}$ & Value of TK top temperature for ORC re-activation & 130 & ${ }^{\circ} \mathrm{C}$ \\
\hline$T_{\text {inORC }}$ & ORC inlet oil temperature & $90-130$ & ${ }^{\circ} \mathrm{C}$ \\
\hline$T_{\text {outORC }}$ & ORC outlet oil temperature & $50-84$ & ${ }^{\circ} \mathrm{C}$ \\
\hline$P_{O R C, \text { rated }}$ & Rated ORC electrical capacity & 50 & $\mathrm{~kW}$ \\
\hline$\eta_{O R C}$ & ORC electrical efficiency & 10 & $\%$ \\
\hline
\end{tabular}

Table 2. CPVT + ORC other parameters

\begin{tabular}{|c|c|c|c|}
\hline Parameter & Description & Value & Unit \\
\hline$L_{\text {side, } 1}$ & Receiver Side 1 Length & 0.60 & $\mathrm{~m}$ \\
\hline$L_{\text {side, } 2}$ & Receiver Side 2 Length & 0.60 & $\mathrm{~m}$ \\
\hline$A_{a p}$ & CPVT aperture area & 12 & $\mathrm{~m}^{2}$ \\
\hline$d$ & Fluid channel diameter & 0.02 & $\mathrm{~m}$ \\
\hline$\alpha_{o p}$ & Top surface absorptance & 0.30 & \\
\hline$\rho_{\text {top }}$ & Top surface reflectance & 0.03 & \\
\hline$\alpha_{\text {conc }}$ & Concentrator absorptance & 0.03 & \\
\hline$\varepsilon_{\text {conc }}$ & Back surface concentrator emissivity & 0.30 & \\
\hline$\varepsilon_{t o p}$ & Top surface emissivity & 0.20 & \\
\hline$\rho_{P V T}$ & PV reflectance & 0.03 & \\
\hline$\varepsilon_{R}, P V T$ & PV emissivity & 0.20 & \\
\hline$d_{c h}$ & Fluid channel diameter & 0.02 & \\
\hline$\eta_{\text {opt }}$ & Optical efficiency & 0.90 & \\
\hline$\eta_{\text {mod }}$ & Module efficiency & 0.90 & \\
\hline$\eta_{i n v}$ & Inverter efficiency & 0.90 & \\
\hline$r_{\text {top }}$ & Top thermal resistance & 3.75 & $\mathrm{~m}^{2 \circ} \mathrm{C} / \mathrm{W}$ \\
\hline$r_{P V T-s u b}$ & PVT-substrate thermal resistance & $3.810^{-4}$ & $\mathrm{~m}^{2 \circ} \mathrm{C} / \mathrm{W}$ \\
\hline$f_{s p}$ & Fluid channel spacing & 0.50 & \\
\hline
\end{tabular}


Table 3. Input design parameters of the ORC machine

\begin{tabular}{|c|c|c|c|}
\hline Parameter & Description & Value & Unit \\
\hline$\overline{t_{T K, \min }}$ & Minumum value of temperature for ORC activation & 90 & ${ }^{\circ} \mathrm{C}$ \\
\hline$P_{O R C, \text { rated }}$ & Rated ORC electricity power & 50 & $\mathrm{~kW}$ \\
\hline \multicolumn{3}{|l|}{ OIL } & $\%$ \\
\hline$\dot{m}$ & Flow rate & 16200 & $\mathrm{~kg} / \mathrm{h}$ \\
\hline$p$ & Pressure & 3 & bar \\
\hline$t_{\text {inORC }}$ & ORC inlet oil temperature & $90-130$ & ${ }^{\circ} \mathrm{C}$ \\
\hline$t_{\text {outORC }}$ & ORC outlet oil temperature & $50-84$ & ${ }^{\circ} \mathrm{C}$ \\
\hline \multicolumn{4}{|l|}{ Water } \\
\hline$\dot{m}$ & Flow rate & 144000 & $\mathrm{~kg} / \mathrm{h}$ \\
\hline$t_{\text {in }}$ & Condenser inlet temperature & 25 & ${ }^{\circ} \mathrm{C}$ \\
\hline$p$ & Pressure & 3 & bar \\
\hline \multicolumn{4}{|l|}{ Evaporator } \\
\hline$L$ & Length & 4.6 & $\mathrm{~m}$ \\
\hline$N$ & Tubes number & 366 & - \\
\hline$D_{s}$ & Shell diameter & 370 & $\mathrm{~mm}$ \\
\hline$d_{o}$ & Tube outside diameter & 17 & $\mathrm{~mm}$ \\
\hline$P T$ & Pitch tube & 25.4 & $\mathrm{~mm}$ \\
\hline$s$ & Tubes thickness & 1.5 & $\mathrm{~mm}$ \\
\hline n tube pass & Number of passes into tubes & 6 & - \\
\hline \multicolumn{4}{|l|}{ Condenser } \\
\hline$L$ & Length & 5 & $\mathrm{~m}$ \\
\hline$N$ & Tubes number & 400 & - \\
\hline$D_{s}$ & Shell diameter & 500 & $\mathrm{~mm}$ \\
\hline$d_{o}$ & Tube outside diameter & 19 & $\mathrm{~mm}$ \\
\hline$P T$ & Pitch tube & 23.75 & $\mathrm{~mm}$ \\
\hline$s$ & Tubes thickness & 1.2 & $\mathrm{~mm}$ \\
\hline n tube pass & Number of passes into tubes & 2 & - \\
\hline$N_{\text {row }}$ & Row number & 40 & - \\
\hline \multicolumn{4}{|l|}{ Expander } \\
\hline$F F$ & Filling factor & 1 & - \\
\hline beta $_{\text {vol }}$ & Positive displacement volume built-in ratio & 3 & - \\
\hline rpm & Rotating speed & 4000 & $\min ^{-1}$ \\
\hline$C C$ & Cubic capacity & 4200 & $\mathrm{~cm}^{3}$ \\
\hline$\eta_{m}$ & Mechanical efficiency & 0,9 & - \\
\hline
\end{tabular}

\section{Systems Model}

Both systems, presented in the previous section, were dynamically simulated in TRNSYS, which is a wellknown software diffusely adopted for both commercial and academic purposes. The software includes a large library of built-in components, often validated by experimental data (Klein, 2006). Such methodology was also used by some of the authors in previous works works (e.g., (Calise, 2010)), where the models of both built-in and user-developed components are discussed in detail.

Here, for sake of brevity, the authors only summarize the simulation models of the two main components recently presented in literature: The Concentrated Photovoltaic Thermal collectors (CPVT) (Buonomano et al., 2013a), the Organic Rankine Cycle (ORC) (Calise et al., 2015; Buonomano et al., 2015). The remaining models are defined in ref. (Calise, 2010). The validation of the system as a whole is not yet possible, since this prototype has never been experimented in literature. Nevertheless, all the results returned by the simulations can be considered highly reliable, since the models of all the components are validated by experimental data and the dynamic approach, included in TRNSYS, is widely adopted in literature for system simulation.

In particular, the models taken from TRNSYS library (tanks, pumps, valves) are validated Vs experimental data. The model of the CPVT collector is validated using experimental data (Buonomano et al., 2013a). Similarly, the model of the ORC is developed according to the best practices available in literature (Calise et al., 2015; Buonomano et al., 2015).

\section{CPVT Model (Buonomano et al., 2013a)}

The CPVT considered in this study consists in a parabolic dish concentrator, equipped with a two-axis tracking system. A planar receiver is placed in the focus of the parabola and it consists of: A InGaP/InGaAs/Ge triple-junction PV layer (Nishioka et al., 2006), a thermal insulation at the top side of the receiver, a metallic substrate including fluid channels, where the fluid to be heated with flows, (Fig. 2). 


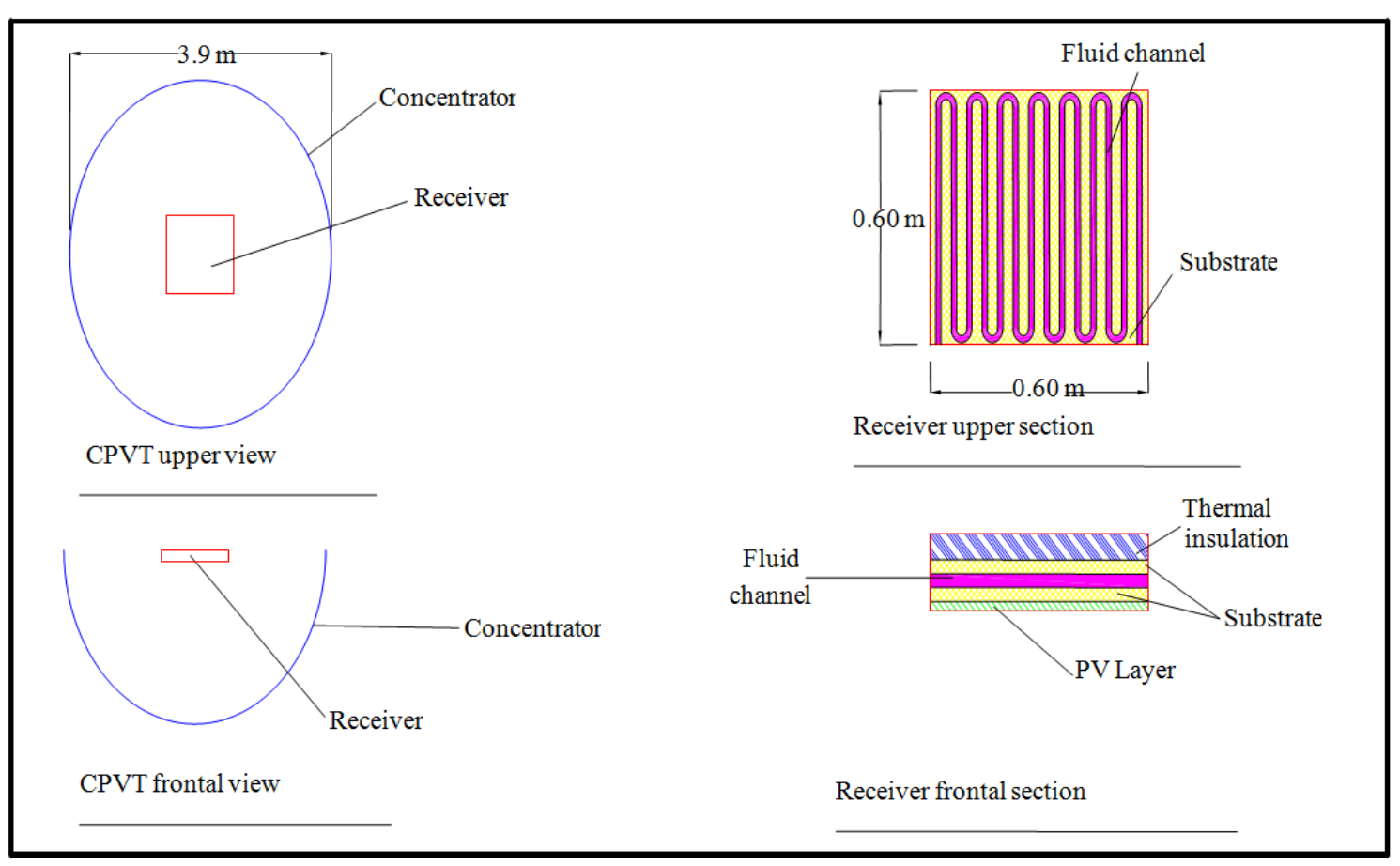

Fig. 2. CPVT layout

Therefore, the concentrated solar irradiation is converted simultaneously in electricity by the PV layer and in thermal energy by the cooling fluid.

In order to simulate the CPVT, a 0 -D model based on energy balances, has been developed and a new Type to be integrated in TRNSYS environment has been created. The model of the CPVT has been developed in Enginnering Equation Solver (EES), which can be easily interfaced with TRNSYS.

Therefore, the model should be sufficiently fast for being used in a quasi-stationary yearly simulation.

The frontal area of the receiver (so for PVT, insulation, metallic substrate layers), $\left(\mathrm{A}_{\text {rec }}\right.$, in the shape of a rectangular with two sides $\mathrm{L}_{\text {side, },}$ and $\mathrm{L}_{\text {side, }, 2}$, is:

$$
A_{\text {rec }}=L_{\text {side, }, 1} \cdot L_{\text {side }, 2}
$$

The concentration ratio is defined as the ratio between the area of the receiver, $A_{r e c}$ and the aperture area, $\mathrm{A}_{a p}$, of the concentrator:

$$
C_{P V T}=\frac{A_{r e c}}{A_{a p}}
$$

The optical efficiency $\left(\eta_{\text {opt }}\right)$ of the concentrator is assumed being constant (Mittelman et al., 2007a). The radiation incident on the receiver surface (PV side, facing the concentrator), is:

$$
G_{P V T}=A_{r e c} I_{b} C_{P V T} \eta_{o p t}
$$

The additional thermal energy absorbed by the top thermal absorber is:

$Q_{t o p}=A_{\text {top }} I_{t o t} \alpha_{t o p}$

Assuming the top surface area as gray surface and considering that the area of the top surface is much lower than the one of the sky, the radiative heat transfer between the top surface (side of insulation facing the sky) and the sky can be calculated as follows (Duffie and Beckman, 1991):

$Q_{t o p-s k y}=A_{t o p} \varepsilon_{R, t o p} \sigma\left(T_{t o p}^{4}-T_{s k y}^{4}\right)$

Similarly, assuming the area of the concentrator much larger than the one of the PVT receiver and assuming both PVT and concentrator as gray surfaces, the radiative heat transfer between the PVT and the concentrator (Duffie and Beckman, 1991):

$Q_{P V T-c o n c}=A_{P V T} \sigma \varepsilon_{R, P V T}\left(T_{P V T}^{4}-T_{\text {conc }}^{4}\right)$

The convective heat transfer between the PVT and the air is calculated as follows (Incropera and DeWitt, 2001):

$Q_{c o n v, P V T}=A_{P V T} h_{c, P V T}\left(T_{P V T}-T_{a}\right)$

The gross electrical power produced by the PV layer is calculated considering the concentrated beam radiation (corrected by the concentrator optical efficiency) 
incident on the PV layer, corrected by the electrical efficiency of the PV, $\eta_{P V}$ :

$$
P_{P V T, \text { gross }}=C_{P V T} A_{P V T} I_{b} \eta_{o p t} \eta_{P V}
$$

The electrical efficiency of the triple-junction PV $\left(\eta_{\text {opt }}\right)$ is experimentally related to the concentration ratio and to the temperature (Mittelman et al., 2007a):

$$
\begin{aligned}
& \eta_{P V}=\left[-715 \cdot 10^{-6}+6769 \cdot 10^{-8} \ln \left(C_{P V T}\right)\right]\left(T_{P V T}-298\right) \\
& +0.298+0.0142 \ln \left(C_{P V T}\right)
\end{aligned}
$$

The net power produced is reduced by the amount of electricity lost in the module connections and in the inverter, considering the corresponding conversion efficiencies ( $\eta_{\text {mod }}$ and $\left.\eta_{i n v}\right)$ (Mittelman et al., 2007a):

$$
P_{P V T, \text { net }}=P_{P V T, \text { gross }} \eta_{\text {mod }} \eta_{\text {inv }}
$$

Finally, the useful heat absorbed by the cooling fluid is:

$$
Q_{u}=\dot{m}_{f}\left(h_{\text {out }}-h_{\text {in }}\right)
$$

The overall energy balance on a control volume including the entire receiver (from PVT to the insulation) is:

$$
\begin{aligned}
& A_{\text {ree }} I_{b} C_{P V T} \eta_{\text {opt }}+A_{\text {top }} I_{\text {tot }} \alpha_{\text {top }}=m_{f}\left(h_{\text {out }} h_{\text {tot }}\right)+ \\
& C_{P V T} A_{\text {rec }} I_{b} \eta_{q t} \eta_{P V} \\
& +A_{\text {rec }} I_{b} C_{P V T} \eta_{o p t} \rho_{P V T}+A_{\text {top }} \varepsilon_{R, t i p} \sigma\left(T_{\text {top }}^{4}-T_{s y y}^{4}\right) \\
& +A_{P V T} \sigma_{\varepsilon R, P V T}\left(T_{P V T}^{4}-T_{\text {onc }}^{4}\right) \\
& +A_{P V T T} h_{c, P V T}\left(T_{P V T}-T_{a}\right)+ \\
& A_{\text {top }} h_{c, \text { top }}\left(T_{\text {top }}-T_{a}\right)
\end{aligned}
$$

A second energy balance considers the control volume, considered as a heat exchanger, including the metallic substrate and the fluid channel (also including the fluid flowing inside):

$$
\dot{m}_{f}\left(h_{\text {out }}-h_{\text {in }}\right)=\varepsilon \dot{m}_{f} c_{f}\left(T_{\text {sub }}-T_{\text {in }}\right)
$$

The third of the required five equations is derived from an energy balance on a control volume including the PVT layer and the metallic substrate:

$A_{\text {rec }} \frac{T_{P V T}-T_{\text {sub }}}{r_{P V T-\text { sub }}}=\dot{m} f\left(h_{\text {out }}-h_{\text {in }}\right)+A_{\text {top }} \frac{T_{\text {sub }}-T_{\text {top }}}{r_{\text {top }}}$

A fourth energy balance can be considered with respect to the control volume including the top side of the substrate and the top surface of the receiver:

$$
\begin{aligned}
& A_{\text {top }} \frac{T_{\text {sub }}-T_{\text {top }}}{r_{\text {top }}}+A_{\text {top }} I_{\text {top }}=A_{\text {top }} I_{\text {top }} \rho_{\text {top }}+ \\
& A_{\text {top }} h_{c, t o p}\left(T_{\text {top }}-T_{a}\right)+A_{\text {top }} \varepsilon_{R, t o p} \sigma\left(T^{4}{ }_{\text {top }}-T^{4}{ }_{\text {sky }}\right)
\end{aligned}
$$

Finally, the last energy balance considers the control volume including only the parabolic dish concentrator:

$$
\begin{aligned}
& A_{P V T} \varepsilon_{R, P V T} \sigma\left(T^{4}{ }_{P V T}-T^{4}{ }_{\text {conc }}\right)+\alpha_{\text {conc }} A_{\text {conc }} I_{\text {top }}= \\
& A_{\text {conc }} \varepsilon_{R, \text { conc b back }} \sigma\left(T^{4}{ }_{\text {conc }}-T^{4}{ }_{\text {sky }}\right)+ \\
& A_{\text {conc }}\left(h_{c, \text { conc, front }}+h_{c, \text { conc }, \text { back }}\right)\left(T_{\text {conc }}-T_{a}\right)
\end{aligned}
$$

The overall performance of the CPVT is often evaluated using the thermal and electrical efficiencies, related to the incident beam radiation and to the collector aperture area:

$\eta_{C P V T, t h}=\frac{\dot{m}_{f}\left(h_{\text {out }}-h_{\text {in }}\right)}{A_{a p} I_{b}}$

$\eta_{C P V T, e l}=\frac{C_{P V T} A_{P V T} I_{b} \eta_{o p t} \eta_{P V}}{A_{a p} I_{b}}$

ORC Model (Calise et al., 2015; Buonomano et al., 2015)

The second system consists of the CPVT collectors and ORC machine. A detailed model of the considered ORC machine (working at variable temperature of the inlet oil to the evaporator) was in-house developed by zero-dimensional energy and mass balances using Engineering Equation Solver (EES). For each component of the ORC machine, there are input variables and specific equations set allowing one to calculate all the useful output parameters on the basis of several assumptions regarding the input variables.

In this ORC simulation model, the input parameters are temperatures, pressures and mass flow rates of: (i) Inlet diathermic oil to the evaporator; (ii) inlet cooling water to the condenser. The code is linked to TRNSYS by these input parameters and by the resulting output ones.

According to the scheme discussed above, an indirect heat transfer is taken into account between the heat source and the ORC machine working fluid (R245fa, according to its performance and critical temperature Vs. those reached by this plant (Calise et al., 2013c)).

The hot diathermic oil is stored in a suitable tank where they obtained thermal energy by the solar field is stored. Note that by such system configuration the undesired boiling process within the solar collectors can be avoided. The temperature of the diathermic oil entering the evaporator may vary as a consequence of the solar radiation availability. Table 3 shows the selected geometric features of condenser and evaporator together with the design temperatures, flow rates and pressures. 
Such data are obtained from an iterative procedure implemented in order to design the $50 \mathrm{~kW}_{\mathrm{e}}$ ORC machine adopted for this study. Such procedure was performed scaling the data regarding a similar ORC previously investigated system.

On the other hand, pump and expander parameters included in Table 3 were obtained from literature and/or manufactures' data, as discussed later on. It is also worth noting that all the features of the heat exchangers shown in Table 3 are consistent with the data included in (Bejan, 1993; Liu and Kakac, 2002; London and Shah, 1978). The developed model allows one to vary both operating parameters (oil and cooling water flow rates and temperatures) and design variables (heat exchangers geometrical features, turbine technology, etc.) analysing system performances and identifying the best plant configuration.

The examined ORC consists of an evaporator, an expander, a condenser and a pump, without super-heater and regeneration process since by the carried out analysis, such components do not significantly improve the overall system energy efficiency.

\section{Evaporator}

The selected evaporator is a shell-and-tube heat exchanger. It consists of a pre-heater and an evaporator. The diathermic oil flows inside the evaporator tubes while the organic fluid fills the shell side. The calculations of the overall heat transfer coefficients of preheating and boiling processes has to be performed separately, due to the difference between single-phase and two-phase behaviors. Hence, the actual heat exchanger has been divided in two different ones, preheater and evaporator, whose total area is equal to the heat transfer area of the actual shell and tube boiler. This approach is widely used in the scientific literature (Quoilin et al., 2011b; Bamgbopa and Uzgoren, 2013; Sun and Li, 2011; Lecompte et al., 2013).

In order to assess the heat exchanger performance, the $\varepsilon-N T U$ method is adopted. The following equation is used for the common shell and tube heat exchangers (Liu and Kakac, 2002):

$$
\varepsilon=\frac{2}{1+\omega+\left(1+\omega^{2}\right)^{1 / 2} \cdot \frac{\left(1+\exp \left[-N T U\left(1+\omega^{2}\right)^{1 / 2}\right]\right)}{\left(1-\exp \left[-N T U\left(1+\omega^{2}\right)^{1 / 2}\right]\right)}}
$$

$$
\begin{gathered}
\omega=\frac{\dot{C}_{\text {max }}}{\dot{C}_{\text {max }}} \\
N T U=\frac{U A}{\dot{C}_{\text {min }}}
\end{gathered}
$$

Empirical methods are adopted for predicting the boiling heat transfer coefficients. In this study, the correlations suggested by Palen (Bejan, 1993; Mostinski et al., 1963) are utilised.

\section{Expander}

The expander design in an ORC machine depends on different working conditions and operating parameters. The main ones are: The required mechanical power, the volumetric expansion ratio, the working fluid type and its mass and volume flow rate (Declaye et al., 2012). For the case investigated in this study, a screw volumetric expander was selected. The input parameters (reported in Table 3 and based on data reported in (Declaye et al., 2012)) are: The positive displacement volume built-in ratio $\left(\right.$ beta $\left._{v o l}\right)$; the expander rotating speed (rpm); the Cubic Capacity (CC); the Filling Factor (FF); the screw expander mechanical efficiency $\left(\eta_{m}\right)$; the condensation and evaporation pressure ( $p_{\text {cond }}$ and $\left.p_{\text {eva }}\right)$; the working fluid mass flow rate, $(\dot{m})$ :

$\dot{m}=\left[\rho\left(p=p_{\text {cond }}, t=t_{\text {cond }}\right)\right] \cdot \frac{C C \cdot r p m}{60} \cdot F F$

Where:

$\rho=$ The density of the organic fluid

For the selected organic working fluid, the calculation of several thermophisical properties is necessary. In particular, the specific heat capacities ( $c p$ and $c v$ ), the specific enthalpy $(h)$, specific entropy $(s)$ are calculated by EES through the following equations:

$k_{\text {del }}=\frac{c_{p, d e l}\left(p=p_{\text {del }}, x=1\right)}{c_{v, d e l}\left(p=p_{\text {del }}, x=1\right)}$

$p_{\text {del }}=p_{\text {eva }} \cdot\left(\frac{1}{\text { beta }_{\text {vol }}}\right)^{k}$

$h_{i s}=h\left(p=p_{\text {cond }}, s=s_{\text {eva }}\right)$

$s=s_{\text {eva }}\left(p=p_{\text {eva }}, x=1\right)$

The specific work of the expander is assessed by:

$$
\begin{aligned}
& w_{1}=h_{\text {eva }}\left(p=p_{\text {eva }}, x=1\right)-h_{\text {del }}\left(p=p_{\text {del }}, s=s_{\text {eva }}\right) \\
& w_{2}=v\left(p=p_{\text {del }}, s=s_{\text {eva }}\right) \cdot\left(p_{\text {del }}-p_{\text {cond }}\right)
\end{aligned}
$$

In Equation $28 v$ is the specific volume of the organic fluid. The output parameters of expanders are calculated as:

$$
\begin{aligned}
& h_{\text {cond }}=h_{\text {eva }}-\frac{\dot{w}_{\text {real }}}{\dot{m}} \\
& \eta_{i s}=\frac{\left(w_{1}+w_{2}\right)}{h_{\text {eva }}-h_{i s}}
\end{aligned}
$$




$$
\begin{aligned}
& \eta_{\text {exp }}=\eta_{\text {is }} \cdot \eta_{m} \\
& \beta_{\text {exp }}=\frac{p_{\text {eva }}}{p_{\text {cond }}} \\
& t_{\text {cond }}=t\left(p=p_{\text {cond }}, h=h_{\text {cond }}\right)
\end{aligned}
$$

The global expander power is assessed by:

$$
\dot{w}_{\text {real }}=\dot{m} \cdot\left(w_{1}+w_{2}\right) \cdot \eta_{i s} \cdot \eta_{m}
$$

\section{Condenser}

The condenser of the examined ORC power plant is designed as a shell and tube heat exchanger. Cooling water flows inside tubes while the organic vapour streams across the finned tube bundle. The organic fluid enters inside the condenser as superheated vapour and exit as saturated liquid.

Since shell and tube condensers are widely analysed and adopted the condensation film process on the tube bundle is a well known and studied phenomena. In this study, the vertical row-number correction method was implemented to analyse the performance of the system condenser (Bejan, 1993). According to this technique the heat transfer coefficient of the shell side is assessed making reference to the film condensation on a single tube, $\bar{h}_{s, t}$. The Nusselt theory is utilised since laminar film condensation of quiescent vapours occurs on isothermal horizontal tubes (Nusselt, 1916):

$$
\bar{h}_{s, t}=0.729 \cdot \frac{\left[\rho_{l} \cdot\left(\rho_{l}-\rho_{v}\right) \cdot g \cdot i_{l v} \cdot k_{l}^{3}\right]}{\mu_{l} \cdot\left(t_{\text {sat }}-t_{\text {wall }}\right) \cdot d_{o}}
$$

Where:

$\bar{h}_{s, t}=$ The heat transfer coefficient of single tube

$\rho=$ The density

$k=$ The thermal conductivity

$m$ = The dynamic viscosity

$t_{\text {sat }}=$ The saturated temperature of organic fluid

$t_{\text {wall }}=$ The wall temperature of condenser

$d_{o}=$ The outer diameter of tubes

The modified latent heat $\left(i_{l v}^{*}\right)$ is introduced in the above mentioned equation for accounting the additional heat delivered during the condensation process. For this reason the organic fluid is extra cooled to an average temperature obtained between $t_{\text {sat }}$ and $t_{\text {wall }}$. $i_{l v}^{*}$ is a function of the latent heat $\left(i_{l v}\right)$ as follows (Bergman et al., 2011):

$i_{l v}^{*}=i_{l v}+0.68 \cdot c_{p l} \cdot\left(t_{\text {sat }}-t_{\text {wall }}\right)$

The system condenser as well as the above mentioned evaporator is arranged with low finned tubes.
Obviously, the heat transfer on such tubes is greater than that on smooth ones. In addition, they exhibit a shorter condensing length also enhancing the surface tension drainage forces along the fins. The tube-side heat transfer coefficient is calculated by the theory suggested by (Rose, 1994) for film condensation on single horizontal trapezoidal finned tubes.

In addition, the Eissenberg equation (Eissenberg, 1972) was adopted for calculating the average heat transfer coefficient for condensation process outside horizontal tubes bundle:

$\bar{h}_{\text {shell }}=\bar{h}_{\text {fun }} \cdot\left(0.6+0.42 \cdot N_{\text {row }}^{-i / 4}\right)$

Where:

$N_{\text {row }}=$ The row number

\section{Pump}

A suitable tool was utilised in order to select the pump to be modelled and the related operating map (Standart Pompa Software (Pompa, 2013)). Such tool requires as input independent variables the volume flow rate and the pump head. The following polynomial equations are utilised for correlating such parameters and the pump efficiency:

$H=a_{1} \cdot \dot{V}^{3}+a_{2} \cdot \dot{V}^{2}+a_{3} \cdot \dot{V}+a_{4}$

$\eta=b_{1} \cdot \dot{V}^{3}+b_{2} \cdot \dot{V}^{2}+b_{3} \cdot \dot{V}+b_{4}$

In these equations the coefficients are obtained by curve fitting of manufacturer data (Table 4).

When the pump runs at different rotating speed the affinity laws for incompressible fluid in rotating machine allows the program to calculate the corresponding pump head and efficiency for a certain volume flow rate (or mass flow rate). These results are achieved by the following Equations 40 and 41:

$\frac{\dot{V}_{\text {real }}}{\dot{V}_{e q}}=\frac{n_{\text {real }}}{n_{\text {eq }}}$

$\frac{H_{\text {real }}}{H_{\text {eq }}}=\left(\frac{n_{\text {real }}}{n_{\text {eq }}}\right)^{2}$

Where:

$H_{\text {real }}$ and $H_{e q}=$ Respectively the real and equivalent hydraulic head

$n_{\text {real }} \quad=$ The rotating speed real

In the above reported equations the equivalent rotating speed $\left(n_{e q}\right)$ is equal to the design value $(2900 \mathrm{rpm})$. 
Table 4. Polynomial coefficients

\begin{tabular}{lllll}
\hline & $\mathrm{i}=1$ & $\mathrm{i}=2$ & $\mathrm{i}=3$ & $\mathrm{i}=4$ \\
\hline$a_{\mathrm{i}}$ & -0.2679 & 0.3338 & -1.308 & 84.59 \\
$b_{\mathrm{i}}$ & 1.5 & -26.03 & 180.10 & \\
\hline
\end{tabular}

The pump head is calculated as:

$$
H_{\text {real }}=\left(\frac{p_{\text {eva }}-p_{\text {cond }}}{\rho_{l} \cdot g}\right)
$$

\section{Economic Model}

The economic analysis was performed for assessing the eventual economic savings obtained by the both examined systems, Vs. a conventional Reference System (RS). The cash flow takes into account the electricity savings considering the electricity production of CPVT collectors (in first system) and one of CPVT collectors and ORC machine (in second system). In RS, electricity is supplied by the national grid. It is worth noting that for both systems, cogenerative heat is not available since heat is rejected at very low temperature (respectively by CPVT and ORC condenser, for the two investigated systems). The yearly economic savings achievable by first and second system are calculated, respectively, by the following equations.

They are strictly related to the net electrical production:

$$
\begin{aligned}
\Delta C_{o p} & =\sum_{t}\left[E_{e l, C P V T, t}+E_{e l, O R C, t}-E_{e l, a u x, t}\right] \cdot c_{E E} \\
\Delta C_{o p} & =\sum_{t}\left[E_{e l, C P V T, t}-E_{e l, a u x, t}\right] \cdot c_{E E}
\end{aligned}
$$

Where:

$E_{e l, C P V T, \mathrm{t}}=$ The electricity produced by the CPVT collectors

$E_{e l, O R C, \mathrm{t}}=$ The electricity produced by the ORC

$E_{e l, a u x, \mathrm{t}}=$ The electricity required by the auxiliary devices (e.g., pumps)

It is assumed that the net power production of the CPVT collectors and ORC machine is entirely delivered to the public grid: In this case, it is assumed that the producer can benefit of a feed-in tariff, $c_{E E}$, equal to $0.35 € / \mathrm{kWh}$.

In the simulation code, a detailed cost model was also implemented, for calculating both operating and capital costs. All the cost functions $\left(J_{\mathrm{i}}\right)$ of the system components (CPVT collectors, pumps, tank, heat exchangers, ORC machine) were considered. The capital costs for pumps, storage tank and heat exchangers are calculated by suitable empirical equations as a function of the nominal flow rate, the volume and heat exchange area, respectively (Calise et al., 2015; Buonomano et al.,
$2013 a ; 2015 ; 2013 b)$. Finally, the economic performance of the both systems are calculated by the Simple Pay Back period (SPB), the Net Present Value (NPV) and the Profit Index (PI). The Annuity Factor (AF) is calculated equal to 12.5 considering a discount rate equal to $5 \%$ and a time horizon of 20 years:

$$
S P B=\frac{\sum_{i} J_{i}}{\Delta C_{o p}}
$$

$$
\begin{aligned}
& N P V=A F \cdot \Delta C_{o p}-\left(\sum_{i} J_{i}\right) \\
& P I=\frac{N P V}{\sum_{i} J_{i}}
\end{aligned}
$$

\section{Results}

As discussed in the previous sections, the aim of this paper is the evaluate the performances of an CPTV coupled or not with an ORC system. The entire plant was designed and simulated in TRNSYS environment.

A base case study was developed using the weather data of Naples, South of Italy. The main design/operational parameters are summarized in Table 1-3. As mentioned above, the dynamic simulation tool developed in this work allows one to use of whatever time basis (seconds, days, weeks, months or one year).

In particular, in this paper the dynamic performance of the system will be shown for a representative summer day and also integrated on weekly and yearly bases. In addition, using yearly-integrated results an economic analysis will be performed, after that a single day will be detailed for both systems. Finally an overall yearly performance parametric analysis will be also provided.

In Fig. 3 the weekly results for a system with CPVT only are shown.

Total and beam solar radiation, CPVT electrical energy and efficiency are shown. It is worth to noting that CPVT can covert only beam radiation which is typically much lower than the available total radiation, as shown in Fig. 3. Such Figure also shows that the calculated electrical efficiency is extremely high, around 25\% all year long (Min: 24.4\%-Max: 25.1\%).

A slight decrease is detected in summer due to the slight increase of CPVT operating temperature, as a consequence of the higher radiation and environmental temperature.

In Fig. 3 it is possible to note that beam radiation during summer season increases and the produced electrical energy by CPVT increases proportionally.

In Fig. 4 weekly results for CPVT coupled with ORC are shown. Obviously, total and beam radiation are the same as shown in Fig. 3. 


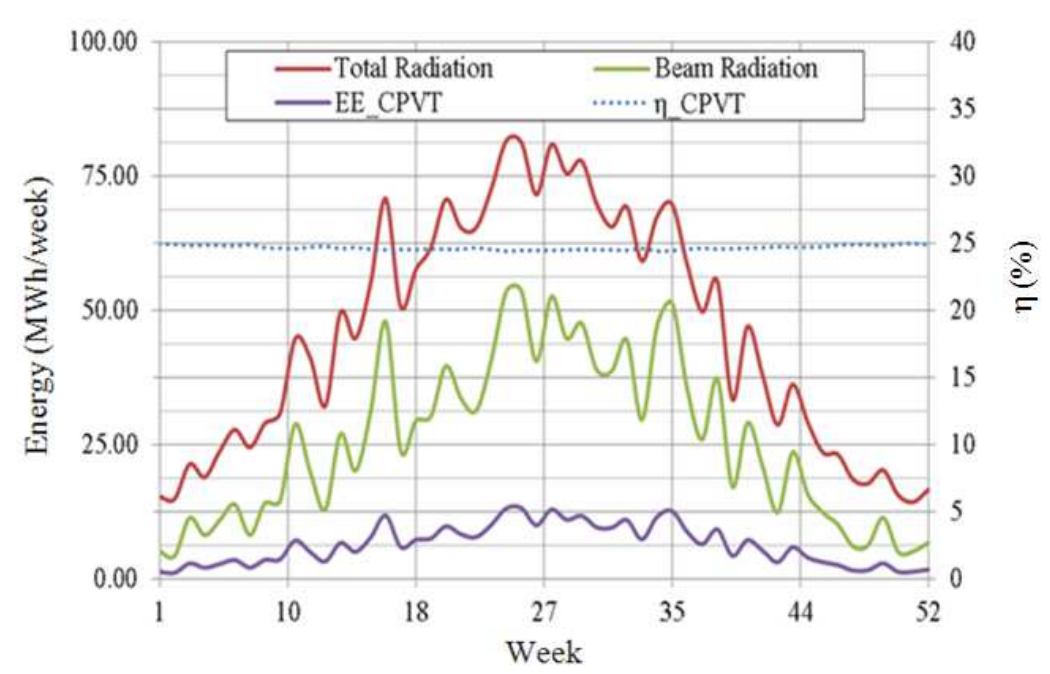

Fig. 3. CPVT only-Weekly results

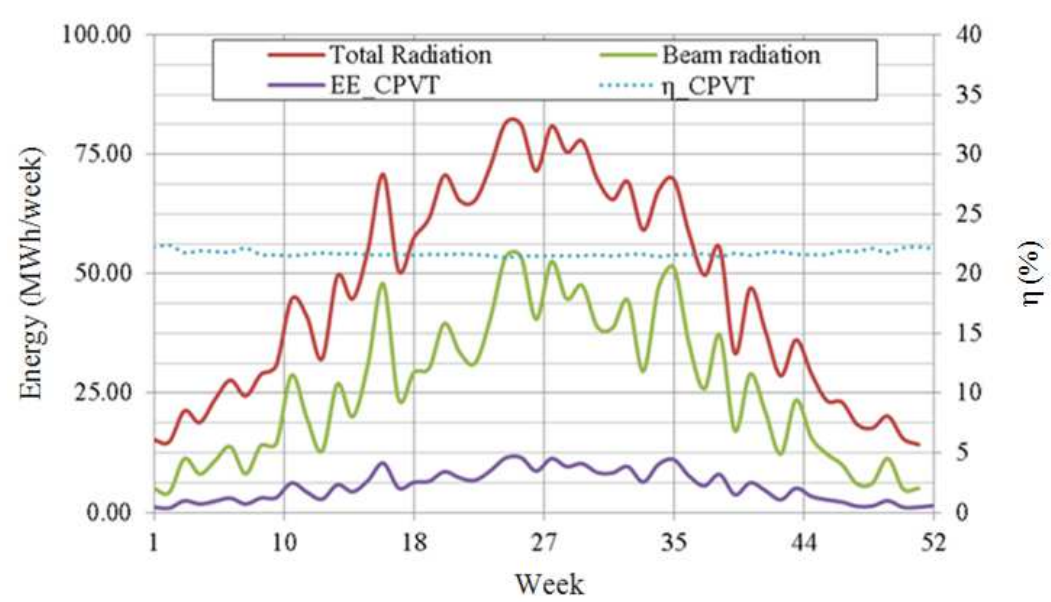

Fig. 4. CPVT+ORC-Weekly results

Conversely, electrical energy produced by CPVT is lower, because in this configuration the operating temperature of the CPVT is around $100^{\circ} \mathrm{C}$ in order to deliver heat to the ORC system. As a consequence, CPVT electrical efficiency is lower, ranging around of $22 \%$ (Min: $21.5 \%$-Max: $22.4 \%$ ). As occurred in the previous case, electrical efficiency slightly decreases in summer season when operative temperature is higher. In this configuration, the ORC performance must be also evaluated.

In Fig. 5 results of the ORC system are shown.

The available thermal energy increases during summer season determining a corresponding increase of the ORC electrical production. ORC efficiency is always around $10 \%$.

Comparing the two graphs it is clearly shown that the combination CPVT+ORC allows one to enhance the overall system electrical production. In fact, the additional electrical energy produced by the ORC is much higher than CPVT electrical production decrease, due to its higher operating temperature.
As mentioned before, for both systems economic parameters are also calculated. Simple Pay Back (SPB), Net Present Value (NVP) and Profit Index (PI) are considered. In Table 5 economic results for both systems are shown.

All the results are calculated using a feeding tariff on electrical energy production of $0,35 € / \mathrm{kWh}$. Here it can be noticed that CPVT system has an higher PI compared to the coupled system.

In fact, CPVT + ORC allows one to achieve an additional electrical production of $8 \%$, with respect to the case of the sole CPVT. Conversely, the capital cost of the coupled CPVT+ORC system is $18 \%$ higher than the one of the other system.

Therefore, from the economic point view the proposed combined system is scarcely competitive since the higher capital cost of the ORC subsystem is not paid back by its additional electrical production.

A dynamic performance result for a representative summer, June 25th, day is also shown (Fig. 6). 


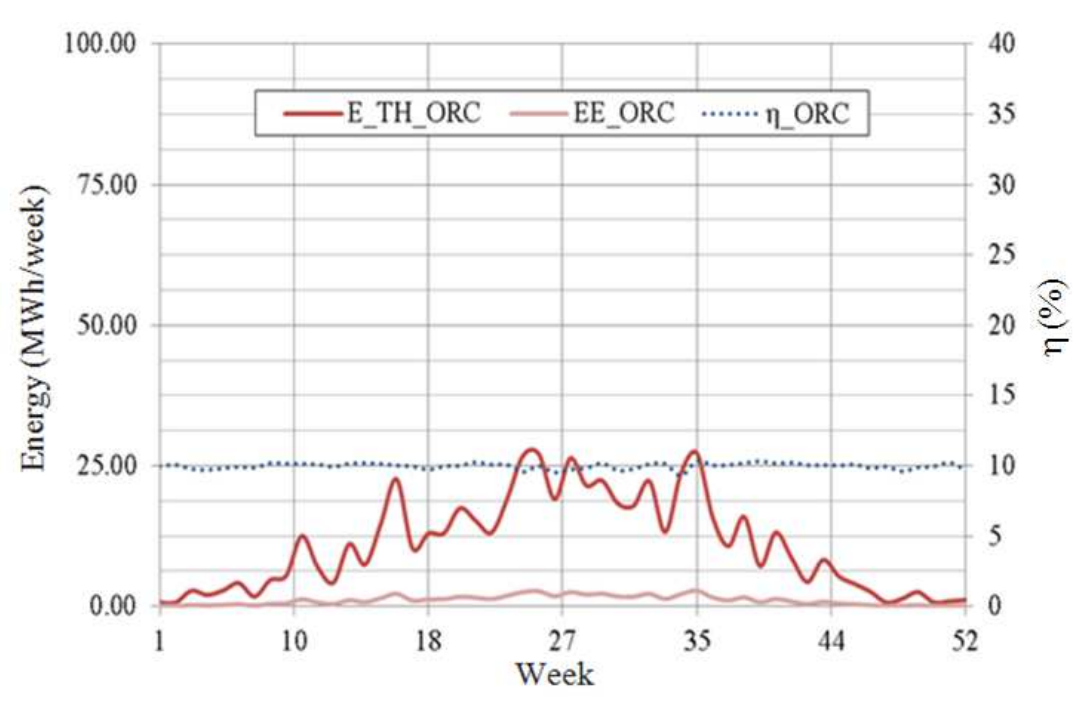

Fig. 5. ORC weekly results

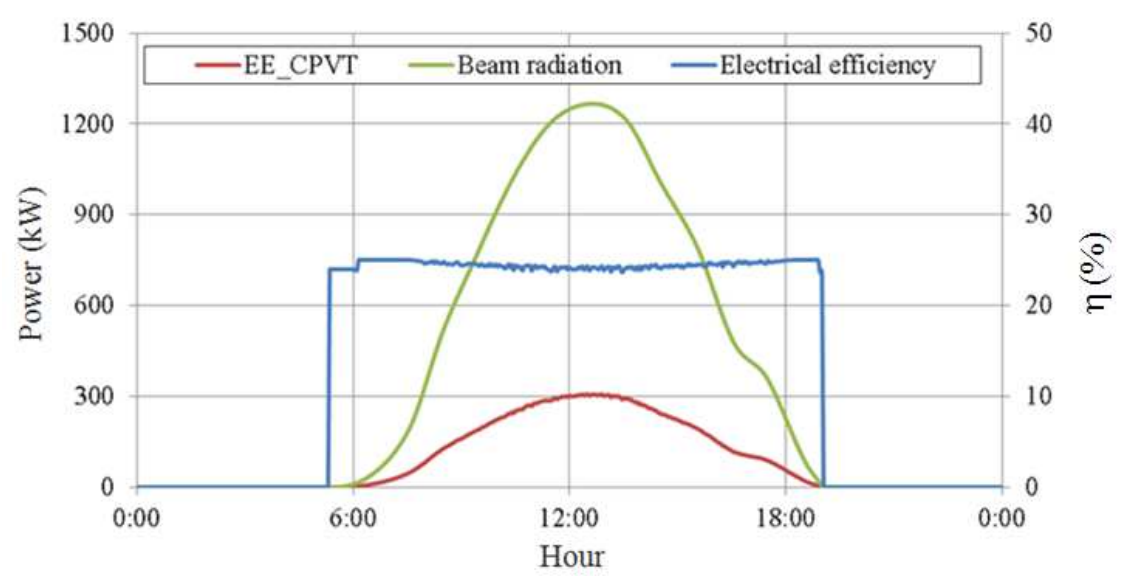

Fig. 6. CPVT only-Daily powers and efficiencies (25th June)

Table 5. Annual results

\begin{tabular}{ll}
\hline Parameters & Value \\
\hline $\mathrm{J}_{\mathrm{CCPVT}}$ & $952000 €$ \\
$\mathrm{~J}_{\mathrm{CCPVT}+\text { ORC }}$ & $1122648 €$ \\
$\Delta \mathrm{C}_{\mathrm{CCPVT}}$ & $112000 €$ \\
$\Delta \mathrm{C}_{\mathrm{CCPVT}+\text { ORC }}$ & $120150 €$ \\
$\mathrm{c}_{\text {feeding }}$ & $0.35 € / \mathrm{kWh}$ el \\
$\mathrm{SPB}_{\mathrm{CCPVT}}$ & 8.49 years \\
$\mathrm{SPB}_{\mathrm{CCPVT}+\text { ORC }}$ & 9.34 years \\
$\mathrm{NPV}_{\mathrm{CCPVT}}$ & $449000 €$ \\
$\mathrm{NPV}_{\mathrm{CCPVT}+\text { ORC }}$ & $379223 €$ \\
$\mathrm{PI}_{\mathrm{CCPVT}}$ & $41,17 \%$ \\
$\mathrm{PI}_{\mathrm{CCPVT}+\mathrm{ORC}}$ & $33,78 \%$ \\
$\eta_{\text {th, CCPVT }}$ & $60.68 \%$ \\
$\eta_{\text {th, CCPVT }+ \text { ORC }}$ & $43,48 \%$ \\
$\eta_{\mathrm{EE}, \text { CCPVT }}$ & $24.57 \%$ \\
$\eta_{\mathrm{EE}, \text { CCPVT }+ \text { ORC }}$ & $21.42 \%$ (collectors) \\
& $10.21 \%$ (ORC) \\
\hline
\end{tabular}

The systems are active from 5:00 to 19:00. Here CPVT efficiency is around $25 \%$ almost constant during the day. For the selected day, the daily solar radiation has a long duration and the amount of beam radiation is around 720 $\mathrm{kWh}$. The electrical energy production is $180 \mathrm{kWh}$.

In the follow the daily performances of the CPVT coupled to an ORC system are shown, for the same representative summer day. In Fig. 7 temperature trends of CPVT, tank and ORC are shown. CPVT outlet temperature reaching the set point value $\left(110^{\circ} \mathrm{C}\right)$ during the whole working period, goes from 7:00 to 18:00.

During central hours of the day, CPVT outlet temperature is even higher than the set-point. This means that, CPVT thermal production is higher than ORC demand and tank storage capacity. The collectors inlet temperature is the same than tank cold side and the ORC inlet temperature is the same than tank hot side. This graph also clearly shows ORC operating strategy. In fact, 
ORC is deactivated until tank hot temperature reaches $130^{\circ} \mathrm{C}$ and it remains activated until such temperature goes below $90^{\circ} \mathrm{C}$. It is also worth noting that when ORC system is activated the temperature difference between ORC inlet and outlet.

In Fig. 8 electrical and thermal performance of the system are shown. ORC electrical efficiency average value is $10 \%$. CPVT production is the same than before but the efficiency of the collectors is slightly lower than before, around $22 \%$.

In order to analyze how design parameters affected the performances, a parametric analysis is also performed. In particular, CPVT area is varied from 70 to $340 \mathrm{~m}^{2}$. Figure 9 shows that electrical energy production increases in both cases.
However, the slope of the CPVT+ORC is lower than the one obtained for the CPVT case. This is due to the simultaneous decrease of both ORC and CPVT efficiencies in case of large solar fields. In fact, when the capacity of the solar field increases, its operating temperature increases as well. The higher the operating temperature of the CPVT is, the lower its electrical efficiency.

Simultaneously, this sharp increase of tank top temperature is not beneficial for the ORC which operates in off-design condition, at lower electrical efficiencies, as shown in Fig. 9. This decrease in electrical efficiency is particularly significant when the CPVT area is higher than $130 \mathrm{~m}^{2}$.

In Fig. 10 the economic analysis is also shown.

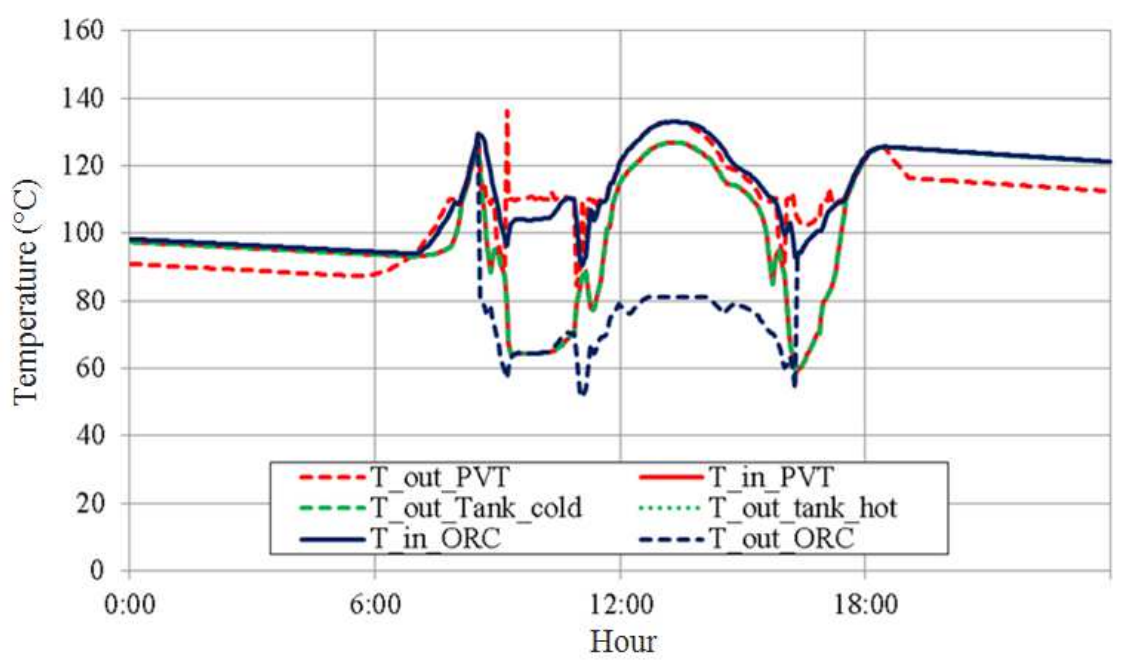

Fig. 7. CPVT+ORC-Daily temperatures (25th June)

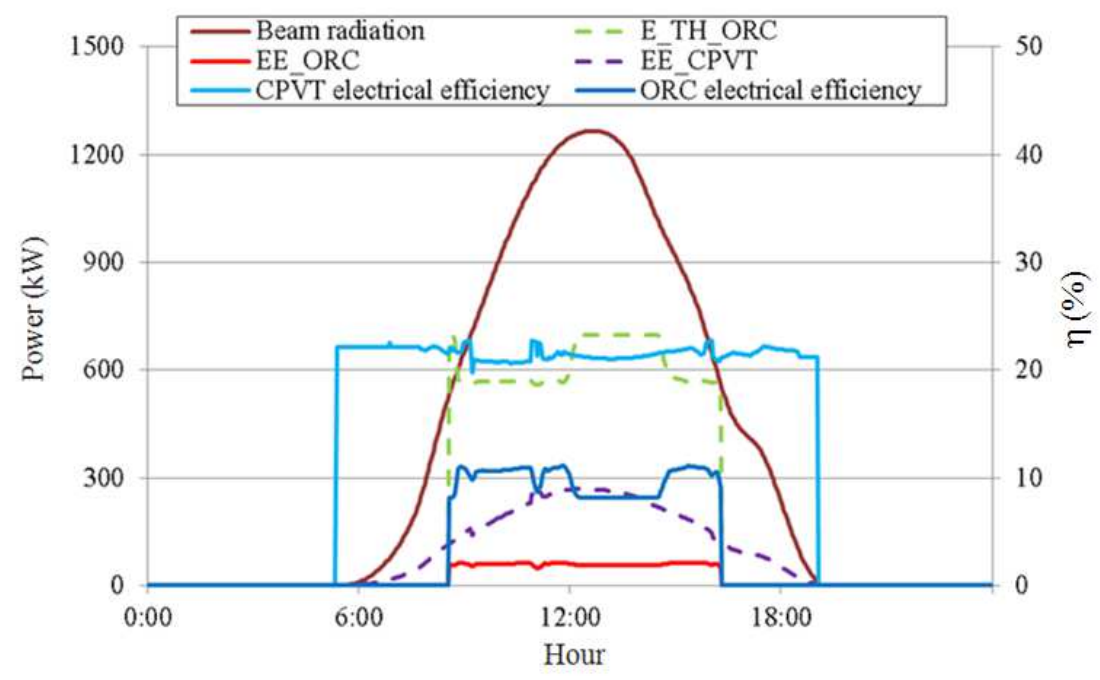

Fig. 8. CPVT+ORC-Daily powers and efficiencies (25th June) 


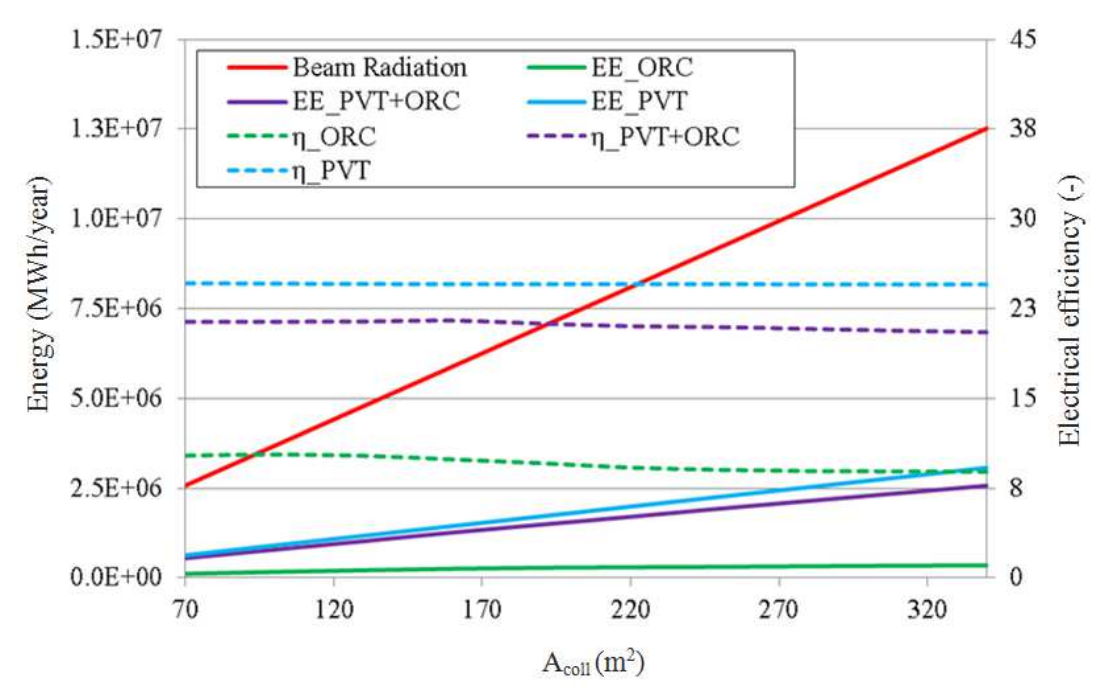

Fig. 9. $\eta$ Parametric analysis-Energy and efficiency VS $A_{\text {coll }}$

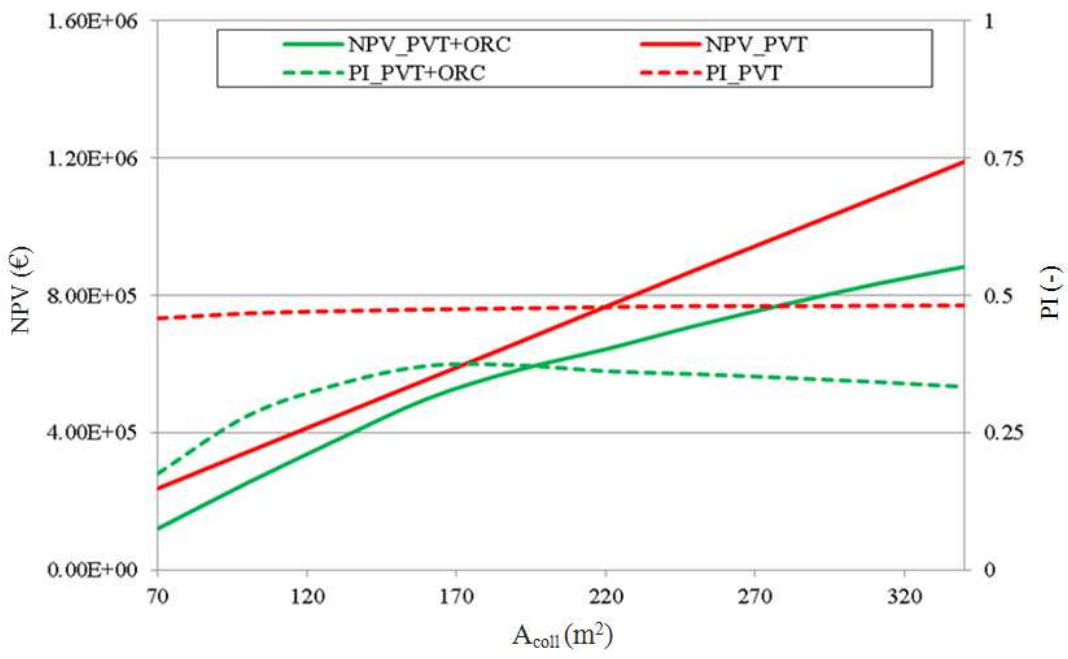

Fig. 10. Parametric analysis-Economic results VS $\mathrm{A}_{\text {coll }}$

As expected, NPV increase in case of large solar fields. Conversely, PI shows a peak of 0.38 for the area of $160 \mathrm{~m}^{2}$ in case of ORC+CPVT, due to the decrease of electrical efficiencies discussed before. In case of CPVT system, IP is scarcely affected by the variations of CPVT area. In no case, PI of the CPVT+ORC system is higher than the one of the CPVT system.

\section{Conclusion}

This paper presents the design a novel solar power plant based on both CPVT and ORC technologies. The basic idea is to use a high temperature CPVT system in order to produce simultaneously electricity and heat to drive a bottomed ORC system, producing additional electrical energy. This novel system, never analysed from both numerical and experimental points of view, is accurately modelled and simulated in TRNSYS environment.

Results of the simulations showed that the novel system allows one to enhance the electrical production of $8 \%$ with respect to a CPVT collector not equipped with an ORC cycle. This result proves the energetic feasibility of the proposed system, showing that additional electrical energy produced by the ORC is higher than CPVT electrical production decrease, due to the higher operating temperature. Unfortunately, the novel system suffers for a higher capital cost (about 18\%) which is dominant over the additional electrical production. A sensitivity analysis also shows that the profitability of the proposed system is greatly affected by the ratio between ORC electrical capacity and CPVT area. In all the cases the profitability of the proposed novel system is good. However, in no case this profitability is better than the one achievable by a simple CPVT system. 
This result suggests that the proposed system is extremely profitable from the energetic point of view. However, a possible future commercialization and a consequent economic profitability can be achieved only in case of a dramatic reduction of ORC capital costs.

\section{Funding Information}

The authors have no support or funding to report.

\section{Author's Contributions}

Francesco Calise: Design of the system. model develpment. analysis of the data.

Massimo Dentice d'Accadia: Design of the system. review of the paper.

Maria Vicidomini: Development of ORC model. Analysis of the data.

Gabriele Ferruzzi: Development of the overall simulation model. Analysis of the data.

Laura Vanoli: Development of ORC model.

\section{Ethics}

This article is original and contains unpublished material. The corresponding author confirms that all of the other authors have read and approved the manuscript and no ethical issues involved.

\section{References}

Bamgbopa, M.O. and E. Uzgoren, 2013. Quasi-dynamic model for an organic Rankine cycle. Energy Convers. Manage., 72: 117-124. DOI: 10.1016/j.enconman.2013.01.040

Bejan, A., 1993. Heat Transfer. 1st Edn., John Wiley and Sons, Inc.

Bergman, T.L., F.P. Incropera and A.S. Lavine, 2011. Fundamentals of Heat and Mass Transfer. 1st Edn., Hoboken, NJ, John Wiley and Sons, ISBN-10: 0470501979, pp: 1048.

Buonomano, A., G. Mittelman and D. Faiman, 2012. Modelling an actively-cooled CPV system. Proceedings of the 8th International Conference on Concentrating Photovoltaic Systems, Apr. 16-18, Toledo, Spain, pp: 235-238. DOI: $10.1063 / 1.4753876$

Buonomano, A., F. Calise, M.D. d'Accadia and L. Vanoli, 2013a. A novel solar trigeneration system based on concentrating photovoltaic/thermal collectors. Part 1: Design and simulation model. Energy, 61: 59-71.

DOI: 10.1016/j.energy.2013.02.009

Buonomano, A., F. Calise and A. Palombo, 2013b. Solar heating and cooling systems by CPVT and ET solar collectors: A novel transient simulation model. Applied Energy, 103: 588-606. DOI: 10.1016/j.apenergy.2012.10.023
Buonomano, A., F. Calise, M.D. d'Accadia, G. Ferruzzi and M. Scarpellino, 2014. Design and simulation of a prototype of a small-scale solar power plant based on evacuated flat-plate solar collectors and Organic Rankine Cycle. Proceedings of the 27th International Conference on Efficiency, Cost, Optimization, Simulation and Environmental Impact of Energy Systems, (IES' 14), Turku, Finland.

Buonomano, A., F. Calise, A. Palombo and M. Vicidomini, 2015. Energy and economic analysis of geothermal-solar trigeneration systems: A case study for a hotel building in Ischia. Applied Energy, 138: 224-241. DOI: 10.1016/j.apenergy.2014.10.076

Calise, F., 2010. Thermoeconomic analysis and optimization of high efficiency solar heating and cooling systems for different Italian school buildings and climates. Energy Build., 42: 992-1003. DOI: $10.1016 /$ j.enbuild.2010.01.011

Calise, F., M.D. d'Accadia and L. Vanoli, 2012. Design and dynamic simulation of a novel solar trigeneration system based on hybrid Photovoltaic/Thermal Collectors (PVT). Energy Convers. Manage., 60: 214-225. DOI: 10.1016/j.enconman.2012.01.025

Calise, F., M.D. d'Accadia, A. Palombo and L. Vanoli, 2013a. Dynamic simulation of a novel hightemperature solar trigeneration system based on concentrating photovoltaic/thermal collectors. Energy, 61: 72-86. DOI: $10.1016 /$ j.energy.2012.10.008

Calise, F., C. Capuozzo and L. Vanoli, 2013b. Design and parametric optimization of an organic rankine cycle powered by solar energy. Am. J. Eng. Applied Sci., 6: 178-204. DOI: 10.3844/ajeassp.2013.178.204

Calise, F., A. Cipollina, M. Dentice d'Accadia and A. Piacentino, 2014a. A novel renewable polygeneration system for a small Mediterranean volcanic island for the combined production of energy and water: Dynamic simulation and economic assessment. Applied Energy, 135: 675-693. DOI: 10.1016/j.apenergy.2014.03.064

Calise, F., M.D. d'Accadia C. Roselli, M. Sasso and F. Tariello, 2014b. Desiccant-based AHU interacting with a CPVT collector: Simulation of energy and environmental performance. Solar Energy, 103: 574-594. DOI: 10.1016/j.solener.2013.11.001

Calise, F., M.D. d'Accadia and A. Piacentino, 2014c. A novel solar trigeneration system integrating PVT (photovoltaic/thermal collectors) and SW (seawater) desalination: Dynamic simulation and economic assessment. Energy, 67: 129-148. DOI: $10.1016 /$ j.energy.2013.12.060

Calise, F., M.D. d'Accadia, M. Vicidomini and M. Scarpellino, 2015. Design and simulation of a prototype of a small-scale solar CHP system based on evacuated flat-plate solar collectors and Organic Rankine Cycle. Energy Convers. Manage., 90: 347-363. DOI: 10.1016/j.enconman.2014.11.014 
Chow, T.T., 2010. A review on photovoltaic/thermal hybrid solar technology. Applied Energy, 87: 365-379. DOI: 10.1016/j.apenergy.2009.06.037

Daghigh, R., I. Adnan, G.L. Jin, M.H. Ruslan and K. Sopian, 2011. Predicting the performance of amorphous and crystalline silicon based photovoltaic solar thermal collectors. Energy Convers. Manage., 52: 41-1747. DOI: 10.1016/j.enconman.2010.10.039

Declaye, S., S. Quoilin and V. Lemort, 2012. Expansion machine and fluid selection for the Organic Rankine Cycle. Proceedings of the 7 th International Conference on Heat Transfer, Fluid Mechanics and Thermodynamics, (FMT' 12), Antalya, Turkey.

Duffie, J.A. and W.A. Beckman, 1991. Solar Engineering of Thermal Processes. 2nd Edn., Wiley, New York, ISBN-10: 0471510564, pp: 944.

Eissenberg, D.M., 1972. An investigation of the variables affective steam condensation on the outside of a horizontal tube bundle. University of Tennessee, Knoxville.

El-Emam, R.S. and I. Dincer, 2013. Exergy and exergoeconomic analyses and optimization of geothermal organic Rankine cycle. Applied Thermal Eng., 59: 435-444.

DOI: 10.1016/j.applthermaleng.2013.06.005

Erdil, E., M. Ilkan and F. Egelioglu, 2008. An experimental study on energy generation with a Photovoltaic (PV)-solar thermal hybrid system. Energy, 33: 1241-1245.

DOI: 10.1016/j.energy.2008.03.005

He, Y.L., D.H. Mei, W.Q. Tao, W.W. Yang and H.L. Liu, 2012. Simulation of the parabolic trough solar energy generation system with Organic Rankine Cycle. Applied Energy, 97: 630-641. DOI: 10.1016/j.apenergy.2012.02.047

Hoffschmidt, B., 2012. Concentrating Solar Power. In: Comprehensive Renewable Energy, Sayigh, A. (Ed.), Newnes, Amsterdam, ISBN-10: 0080878733, pp: 595-636.

Hung, T.C., S.K. Wang, C.H. Kuo, B.S. Pei and K.F. Tsai, 2010. A study of organic working fluids on system efficiency of an ORC using low-grade energy sources. Energy, 35: 1403-1411. DOI: $10.1016 /$ j.energy.2009.11.025

Incropera, F.P. and D.P. DeWitt, 2001. Fundamentals of Heat and Mass Transfer. 5th Edn., Wiley, New York, ISBN-10: 047120448X, pp: 1008.

Kane, M., D. Larrain, D. Favrat and Y. Allani, 2003. Small hybrid solar power system. Energy, 28: 1427-1443. DOI: 10.1016/S0360-5442(03)00127-0

Klein, S.A., 2006. TRNSYS: A transient system simulation program. Solar Energy Laboratory, University of Wisconsin, Madison.

Kosmadakis, G., D. Manolakos and G. Papadakis, 2011. Simulation and economic analysis of a CPV/thermal system coupled with an organic Rankine cycle for increased power generation. Solar Energy, 85: 308-324. DOI: 10.1016/j.solener.2010.11.019
Kribus, A., D. Kaftori, G. Mittelman, A. Hirshfeld and Y. Flitsanov et al., 2006. A miniature concentrating photovoltaic and thermal system. Energy Convers. Manage., 47: 3582-3590.

Ksayer, E.B.L., 2011. Design of an ORC system operating with solar heat and producing sanitary hot water. Energy Procedia, 6: 389-395. DOI: $10.1016 /$ j.egypro.2011.05.045

Kuo, C.R., K.H. Chang and C.C. Wang, 2011. Analysis of a $50 \mathrm{~kW}$ organic Rankine cycle system. Energy, 36: 5877-5885. DOI: 10.1016/j.energy.2011.08.035

Lecompte, S., H. Huisseune, M. van den Broek, S.D. Schampheleire and M.D. Paepe, 2013. Part load based thermo-economic optimization of the Organic Rankine Cycle (ORC) applied to a Combined Heat and Power (CHP) system. Applied Energy, 111: 871-881. DOI: 10.1016/j.apenergy.2013.06.043

Li, M., G.L. Li, X. Ji, F. Yin and L. Xu, 2011a. The performance analysis of the trough concentrating solar photovoltaic/thermal system. Energy Convers. Manage., 52: 2378-2383. DOI: 10.1016/j.enconman.2010.12.039

Li, M., J. Xu, L. Guoliang, S. Wei, Y.F. Li and F. Shi, 2011b. Performance study of solar cell arrays based on a trough concentrating photovoltaic/thermal system. Applied Energy, 88: 3218-3227. DOI: 10.1016/j.apenergy.2011.03.030

Li, M., X. Ji, G.L. Li, Z.M. Yang, S.X. Wei and L.L. Wang, 2011c. Performance investigation and optimization of the trough concentrating photovoltaic/thermal system. Solar Energy, 85: 1028-1034. DOI: 10.1016/j.solener.2011.02.020

Liu, H. and S. Kakac, 2002. Solutions Manual for Heat Exchangers: Selection, Rating and Thermal Design. 2nd Edn., Taylor and Francis Group, ISBN-10: 0849314151.

London, A.L. and R.K. Shah, 1978. Laminar Flow Forced Convection in Ducts: A Source Book for Compact Heat Exchanger Analytical Data. 1st Edn., Academic Press, New York, ISBN-10: 0120200511, pp: 477.

Madhawa, H.D., M.G. Hettiarachchi, W.M. Worek and Y. Ikegami, 2007. Optimum design criteria for an Organic Rankine cycle using low-temperature geothermal heat sources. Energy, 32: 1698-1706. DOI: 10.1016/j.energy.2007.01.005

Mittelman, G., A. Kribus and A. Dayan, 2007a. Solar cooling with Concentrating Photovoltaic/Thermal (CPVT) systems. Energy Convers. Manage., 48: 2481-2490. DOI: 10.1016/j.enconman.2007.04.004

Mittelman, G., A. Kribus, O. Mouchtar and A. Dayan, 2007b. Water desalination with Concentrating Photovoltaic/Thermal (CPVT) systems. Solar Energy, 83: 1322-1334.

DOI: 10.1016/j.solener.2009.04.003 
Mostinski, I.L., 1963. Application of the Rule of Corresponding States for Calculation of Heat Transfer and Critical Heat Flux. Teploenergetika, 4: 66-66.

Nishioka, K., T. Takamoto, T. Agui, M. Kaneiwa and Y. Uraoka et al., 2006. Annual output estimation of concentrator photovoltaic systems using highefficiency $\mathrm{InGaP} / \mathrm{InGaAs} / \mathrm{Ge}$ triple-junction solar cells based on experimental solar cell's characteristics and field-test meteorological data. Solar Energy Mater. Solar Cells, 90: 57-67. DOI: 10.1016/j.solmat.2005.01.011

Nusselt, W., 1916. The condensation of steam on cold surface. Z.d. Ver. Deut. Ing., 60: 541-541.

Pompa, S., 2013. Online Pump Selection.

Price, H.W. and V. Hassani, 2002. Modular trough power plant cycle and systems analysis. National Renewable Energy Laboratory, Golden, CO., pp: 118.

Quoilin, S., M. Orosz, H. Hemond and V. Lemort, 2011a. Performance and design optimization of a low-cost solar organic Rankine cycle for remote power generation. Solar Energy, 85: 955-966. DOI: 10.1016/j.solener.2011.02.010

Quoilin, S., R. Aumann, A. Grill, A. Schuster and V. Lemorta et al., 2011b. Dynamic modeling and optimal control strategy of waste heat recovery organic Rankine Cycles. Applied Energy, 88: 2183-2190. DOI: 10.1016/j.apenergy.2011.01.015

Quoilin, S., V. Lemort and J. Lebrun, 2010. Experimental study and modeling of an Organic Rankine Cycle using scroll expander. Applied Energy, 87: 1260-1268. DOI: 10.1016/j.apenergy.2009.06.026

Rose, J.W., 1994. An Approximate Equation for the Vapour-Side Heat-Transfer Coefficient for Condensation on Low-Finned Tubes. Int. J. Heat Mass Transfer, 37: 865-875.

DOI: 10.1016/0017-9310(94)90122-8

Sun, J. and W. Li, 2011. Operation optimization of an Organic Rankine Cycle (ORC) heat recovery power plant. Applied Thermal Eng., 31: 2032-2041. DOI: 10.1016/j.applthermaleng.2011.03.012

Tripanagnostopoulos, Y., 2007. Aspects and improvements of hybrid photovoltaic/thermal solar energy systems. Solar Energy, 81: 1117-1131.

Vorobiev, Y., J. González-Hernández, P. Vorobiev and L. Bulat, 2006. Thermal-photovoltaic solar hybrid system for efficient solar energy conversion. Solar Energy, 80: 170-176.

DOI: 10.1016/j.solener.2005.04.022

Yamamoto, T., T. Furuhata, N. Arai and K. Mori, 2001. Design and testing of organic rankine cycle. Energy, 26: 239-251. DOI: 10.1016/S0360-5442(00)00063-3

Yiping, D., J. Wang and L. Gao, 2009. Parametric optimization and comparative study of Organic Rankine Cycle (ORC) for low grade waste heat recovery. Energy Convers. Manage., 50: 576-582. DOI: $10.1016 /$ j.enconman.2008.10.018

\section{Nomenclature}

A

$\mathrm{b}$

$\dot{C}$

c

$\mathrm{c}_{\mathrm{p}}$

$\mathrm{C}_{\mathrm{PVT}}$

d

$\mathrm{d}_{\mathrm{o}}$

$\mathrm{D}_{\mathrm{s}}$

D

e

$\mathrm{f}$

$\mathrm{F}_{\mathrm{b}}$

$\mathrm{F}_{\mathrm{c}}$

$f_{\text {sp }}$

$\mathrm{g}$

$\mathrm{G}_{\mathrm{PVT}}$

$\mathrm{H}$

$\mathrm{h}$

$\mathrm{h}_{\mathrm{c}}$

$\mathrm{h}_{\mathrm{f}}$

$\mathrm{I}_{\mathrm{b}}$

$\mathrm{i}_{\mathrm{lv}}$

$\mathrm{I}_{\text {tot }}$

$\mathrm{k}$

$\mathrm{L}$

$\dot{m}$

$\mathrm{n}$

$\mathrm{N}$

$\mathrm{Nu}$

$\overline{\mathrm{Nu}}$

$\mathrm{N}_{\text {row }}$

NUT

$\mathrm{n}_{\text {tubepass }}$

$\mathrm{p}$

$P_{\text {PVT }}$

$\mathrm{Pr}$

PT

$Q$

$\dot{Q}$

$r$

Re

$\mathrm{S}$

T

$\mathrm{U}$

$\dot{V}$

W

W

$\dot{w}_{\text {real }}$ area $\left(\mathrm{m}^{2}\right)$

fin spacing (m)

heat capacity rate $\left(\mathrm{kJ} \mathrm{kg}^{-1} \mathrm{~K}^{-1}\right)$

specific Heat $(\mathrm{J} / \mathrm{kg} / \mathrm{K})$

specific heat at constant

pressure $\left(\mathrm{kJ} \mathrm{kg}^{-1} \mathrm{~K}^{-1}\right)$

concentration ratio

fluid channel diameter (m)

tube diameter $(\mathrm{mm})$

shell diameter $(\mathrm{mm})$

diameter $(m)$

fin height (m)

fin thickness $(\mathrm{m})$

bundle boiling factor (-)

mixture boiling correlation factor (-)

function of the ratio

gravitat. acceleration $\left(\mathrm{m} \mathrm{s}^{-2}\right)$

incident radiative Flow $(\mathrm{W})$

hydraulic Head (m)

heat transfer coefficient $\left(\mathrm{W} \mathrm{m}^{-2} \mathrm{~K}\right)$

convective heat transfer coefficient

$\left(\mathrm{W} \mathrm{m} \mathrm{m}^{-2} \mathrm{~K}\right)$

fluid specific Enthalpy $\left(\mathrm{J} \mathrm{kg}^{-1}\right)$

beam radiation $\left(\mathrm{W} \mathrm{m}^{-2}\right)$

latent heat of evaporation $\left(\mathrm{kJ} \mathrm{kg}^{-1} \mathrm{~K}^{-1}\right)$

total radiation $\left(\mathrm{W} \mathrm{m}^{-2}\right)$

conductivity ( $\mathrm{W} \mathrm{m} \mathrm{K}$ )

length (m)

mass flow rate $\left(\mathrm{kg} \mathrm{s}^{-1}\right)$

Number of channels(-)

number of tubes (-)

Nusselt Number(-)

Nusselt number (-)

number of row (-)

number of Transfer Unit (-)

number of passes into tubes (-)

pressure $(\mathrm{kPa})$

PVT Electrical Power (W)

Prandtl number (-)

Pitch Tube (mm)

heat $(\mathrm{Wh})$

thermal Power (W)

area specific thermal resistance $\left(\mathrm{m}^{2} \mathrm{~K} \mathrm{~W}^{-1}\right)$

Reynolds number (-)

tubes thickness (mm)

temperature $(\mathrm{K})$

temperature $\left({ }^{\circ} \mathrm{C}\right)$

overall heat transfer coefficient $\left(\mathrm{W} \mathrm{m}^{-2} \mathrm{~K}^{-1}\right)$

volume flow rate $\left(\mathrm{m}^{3} \mathrm{~s}^{-1}\right)$

velocity $\left(\mathrm{m} \mathrm{s}^{-1}\right)$

specific work $\left(\mathrm{kJ} \mathrm{kg}^{-1}\right)$

gross power $(\mathrm{kW})$ 


\begin{tabular}{|c|c|c|c|}
\hline \multicolumn{2}{|c|}{ Greek Symbols Greek Symbols } & id & Ideal \\
\hline$\alpha$ & absorptance (-) & in & Inlet \\
\hline$\beta$ & angle at the fin tip & ins & Insulation \\
\hline$\beta_{\exp }$ & angle at the fin tip & is & Isentropic \\
\hline$\varepsilon$ & heat exchanger efficiency (-) & 1 & Liquid \\
\hline$\varepsilon_{\mathrm{R}}$ & emittance $(-)$ & $\max$ & Maxim \\
\hline$\eta_{\text {inv }}$ & inverter efficiency (-) & $\min$ & Minimum \\
\hline$\eta_{\text {mod }}$ & module efficiency (-) & natural & Natural convection \\
\hline$\eta_{\mathrm{PV}}$ & PV efficiency (-) & $\mathrm{nb}$ & Nucleate boiling \\
\hline $\begin{array}{l}\eta_{\mathrm{PV}} \\
\eta_{\mathrm{opt}}\end{array}$ & optical efficiency (-) & net & Net \\
\hline$\eta_{\text {opt }}$ & $\begin{array}{l}\text { optical efficiency (-) } \\
\text { thermal efficiency }(-)\end{array}$ & $\mathrm{O}$ & Outer \\
\hline$\eta_{\text {th }}$ & & oil & Diathermic oil \\
\hline$\eta_{\mathrm{el}}$ & electrical efficiency (-) & out & Outlet \\
\hline$\theta$ & hour of the day (h) & plate & Square receiver \\
\hline$\mu$ & dynamic viscosity $\left(\mathrm{kg} \mathrm{m}^{-1} \mathrm{~s}^{-1}\right)$ & PVT & PhotoVoltaic Thermal \\
\hline$\rho$ & density $\left(\mathrm{kg} \mathrm{m}^{-3}\right)$ & real & Real \\
\hline$\rho_{\text {PVT }}$ & PVT Reflectance (-) & rec & Receiver \\
\hline$\sigma$ & surface tension $\left(\mathrm{N} \mathrm{m}^{-1}\right)$ & sat & Saturated \\
\hline$\sigma$ & Stephan-Botzmann constant $\left(\mathrm{W} \mathrm{m}^{-2} \mathrm{~K}^{-4}\right)$ & shell & Shell \\
\hline$\Phi f$ & Condensate retention angle & $\begin{array}{l}\text { side } \\
\text { sky }\end{array}$ & $\begin{array}{l}\text { Side of the rectangle } \\
\text { Referred to sky }\end{array}$ \\
\hline Subsc & & $\mathrm{s}, \mathrm{t}$ & Single tube \\
\hline $\mathrm{a}$ & Ambient & $s u b$ & Substrate \\
\hline ap & Aperture & $\mathrm{t}$ & Referred to the value of a parameter in time \\
\hline avg & Average & & step \\
\hline back & Back surface & th & Thermal \\
\hline c & Cold fluid & tot & Total \\
\hline$c h$ & Channel & top & Top surface \\
\hline conc & Concentrator & $u$ & Useful \\
\hline cond & Condenser & $v$ & Vapour \\
\hline conv & Convective & Acronyms & \\
\hline crit & Critical & $A F$ & Annuity Factor \\
\hline del & Delivery & $C P V T$ & Concentrating PhotoVoltaic \\
\hline el & Electrical & & Thermal solar collectors \\
\hline eq & Equivalent & $I A M$ & Incident Angle Modifier \\
\hline est & Finned tube outer & $N P V$ & Net Present Value \\
\hline eva & Evaporator & $O R C$ & Organic Rankine Cycle \\
\hline exit & Exit & $P I$ & Profit Index \\
\hline$f$ & Fluid & $P V$ & PhotoVoltaic \\
\hline fin & Fin & $P V T$ & PhotoVoltaic Thermal solar collectors \\
\hline gross & Gross & $R S$ & Conventional reference system \\
\hline $\mathrm{h}$ & Hot fluid & $S P B$ & Simple Pay Back period \\
\hline$H E X$ & Heat EXchanger & $S C$ & Solar collectors \\
\hline
\end{tabular}

